$12-2009$

\title{
The Objectives and Principles of the TRIPS Agreement
}

Peter K. Yu

peter_yu@msn.com

Follow this and additional works at: https://scholarship.law.tamu.edu/facscholar

Part of the Intellectual Property Law Commons, and the International Trade Law Commons

\section{Recommended Citation}

Peter K. Yu, The Objectives and Principles of the TRIPS Agreement, 46 Hous. L. Rev. 979 (2009).

Available at: https://scholarship.law.tamu.edu/facscholar/457

This Article is brought to you for free and open access by Texas A\&M Law Scholarship. It has been accepted for inclusion in Faculty Scholarship by an authorized administrator of Texas A\&M Law Scholarship. For more information, please contact aretteen@law.tamu.edu. 


\title{
ARTICLE
}

\section{THE OBJECTIVES AND PRINCIPLES OF THE TRIPS AGREEMENT}

\author{
Peter K. Yu* \\ TABLE OF CONTENTS
}

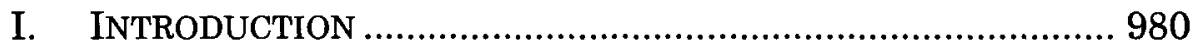

II. ORIGINS AND DEVELOPMENT ........................................... 982

A. The TRIPS Negotiations ............................................ 982

B. Trade-Related Aspects of IPRs ..................................... 984

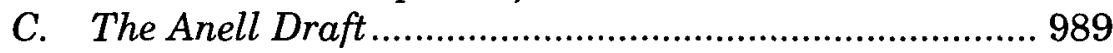

D. The WTO Panel's Clarification ................................... 992

E. The Doha Fortifications ................................................ 994

F. An Elevated Legal Status? ........................................ 997

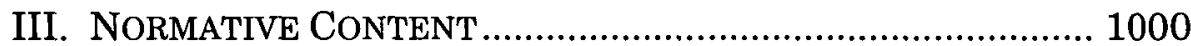

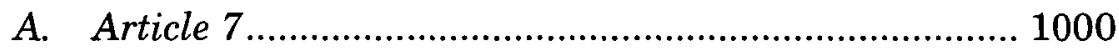

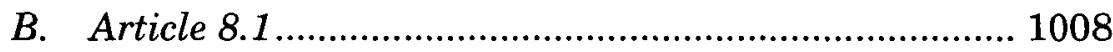

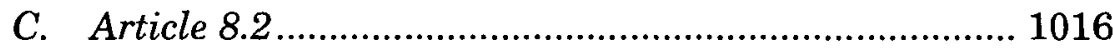

* Copyright (C) 2009 Peter K. Yu. Kern Family Chair in Intellectual Property Law \& Director, Intellectual Property Law Center, Drake University Law School; Wenlan Scholar Chair Professor, Zhongnan University of Economics and Law; Visiting Professor of Law, Faculty of Law, University of Hong Kong. An earlier version of this Article was presented at the 2009 Santa Fe conference organized by the University of Houston Law Center, at the "Intellectual Property and Social Justice" Symposium at Hokkaido University School of Law in Sapporo, Japan, and as a lecture at Zhongnan University of Economics and Law in Wuhan, China. The Author would like to thank Craig Joyce, Greg Vetter, and Yoshiyuki Tamura for their kind invitations and hospitality, and Carlos Correa for his invitation to contribute a shorter version of this Article to his Research Handbook on the Protection of Intellectual Property Under WTO Rules. The Author is also grateful to Ricardo Colmenter, Rochelle Dreyfuss, Cynthia Ho, Edward Lee, Jacqueline Lipton, Charles McManis, Jerome Reichman, Greg Vetter, and Mary Wong for their valuable comments and suggestions, and Jonathan Soike and Megan Snyder for excellent research and editorial assistance. 
IV. MULTIPLE USES OF ARTICLES 7 AND 8 ............................ 1018

A. Guiding Light ........................................................ 1020

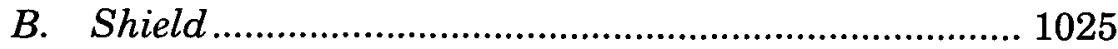

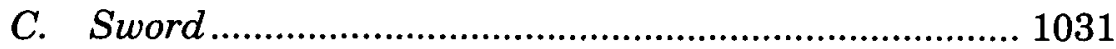

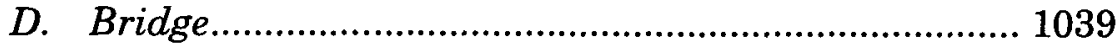

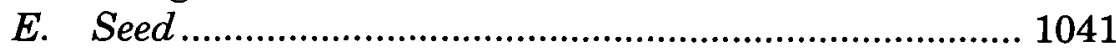

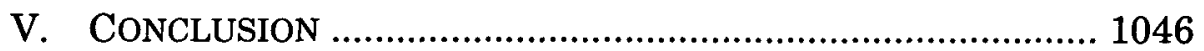

\section{INTRODUCTION}

The Agreement on Trade-Related Aspects of Intellectual Property Rights (TRIPS Agreement), ${ }^{1}$ which established the minimum standards for the protection and enforcement of intellectual property rights for members of the World Trade Organization (WTO), is one of the more controversial international intellectual property agreements that have entered into force. Its negotiations were highly contentious, ${ }^{2}$ and the perspectives of developed and less-developed countries on the role of intellectual property protection and enforcement remain far apart.

In recent years, less-developed countries-including both developing and least-developed countries-have expressed their deep dissatisfaction with the way the TRIPS Agreement has been interpreted and implemented. They are also frustrated by the ongoing demands by developed countries for protections that are in excess of what they promised during the TRIPS negotiationsoften through new bilateral and regional trade and investment agreements. As they claim, the Agreement as interpreted by their developed trading partners and the additional "TRIPS-plus" demands "ignore their local needs, national interests, technological capabilities, institutional capacities, and public health conditions." ${ }^{3}$ These concerns and frustrations eventually led to the establishment of a set of development agendas at the

1. Agreement on Trade-Related Aspects of Intellectual Property Rights [hereinafter TRIPS Agreement], Apr. 15, 1994, Marrakesh Agreement Establishing the World Trade Organization, Annex 1C, Legal Instruments-Results of the Uruguay Round, 33 I.L.M. 1125 (1994) [hereinafter Marrakesh Agreement].

2. See generally DANIEL GERVAIS, THE TRIPS AGREEMENT: DRAFTING HISTORY AND ANALYSIS 3-26 (2d ed. 2003) (describing the origins and development of the TRIPS Agreement); Jayashree Watal, INTEllectual Property Rights in the WTO aND DEVELOPING COUNTRIES 11-47 (2001) (recounting the negotiation process for the TRIPS Agreement); Peter K. Yu, TRIPs and Its Discontents, 10 MARQ. INTELL. PROP. L. ReV. 369, 371-79 (2006) (examining four different accounts of the origins of the TRIPS Agreement).

3. Peter K. Yu, The International Enclosure Movement, 82 IND. L.J. 827, 828 (2007). 
WTO, the World Intellectual Property Organization (WIPO), and other international fora. ${ }^{4}$

Although the TRIPS Agreement's one-size-fits-all-or, more precisely, super-size-fits-all ${ }^{5}$-approach is highly problematic, the Agreement includes a number of flexibilities to facilitate development and to protect the public interest. ${ }^{6}$ To safeguard these flexibilities, Articles 7 and 8 provide explicit and important objectives and principles that play important roles in the interpretation and implementation of the Agreement. This Article explores the origins of these two provisions and the roles they can play in promoting the development goals of less-developed countries.

Thus far, a growing amount of scholarship has offered detailed article-by-article commentaries on the TRIPS Agreement. ${ }^{7}$ This Article therefore does not seek to repeat these admirably accomplished tasks. Instead, it builds on the available materials and explains how Articles 7 and 8 can play multiple roles in helping less-developed countries preserve the hard-earned bargains they won through the TRIPS negotiations. The Article further discusses how these provisions can be used to recalibrate the balance of the international intellectual property system.

4. See Peter K. Yu, A Tale of Two Development Agendas, 35 OHIO N.U. L. REV. 465, 511-40 (2009) (discussing the development agendas at various international fora).

5. See Shamnad Basheer \& Annalisa Primi, The WIPO Development Agenda: Factoring in the "Technologically Proficient" Developing Countries, in IMPLEMENTING THE WORld InTEllectual Property ORGanization's DeVElopment AgENDa 100, 110 (Jeremy de Beer ed., 2009) (alluding to the "one-'super-size'-fits-all model"); James Boyle, A Manifesto on WIPO and the Future of Intellectual Property, 2004 DUKE L. \& TECH. REV. 9, at 3-4, http://www.law.duke.edu/journals/dltr/articles/pdf/2004DLTR0009.pdf ("One size fits all. And it is 'extra large."'); Jeremy de Beer, Defining WIPO's Development Agenda, in IMPLEMENTING THE WORLD INTELLECTUAL PROPERTY ORGANIZATION'S DEVELOPMENT AGENDA, supra, at 1, 3 (referring to "a one-size, especially a supersize, model of global IP law").

6. As Frederick Abbott pointed out in the public health context:

The TRIPS Agreement... does not ... restrict the authority of governments to regulate prices. It ... permits [compulsory or government-use licenses] to be granted. It permits governments to authorize parallel importation. The TRIPS Agreement does not specify that new-use patents must be granted. It allows patents to be used for regulatory approval purposes, and it does not require the extension of patent terms to offset regulatory approval periods. The TRIPS Agreement provides a limited form of protection for submissions of regulatory data; but this protection does not prevent a generic producer from making use of publicly available information to generate bioequivalence test data. The TRIPS Agreement provides substantial discretion for the application of competition laws.

Frederick M. Abbott, The Cycle of Action and Reaction: Developments and Trends in Intellectual Property and Health, in NEGoTIATING HEALTH 27, 30 (Pedro Roffe et al. eds., 2006) (citations omitted).

7. For article-by-article commentaries on Articles 7 and 8, see CARLOS M. CORREA, TRADE RELATED ASPECTS OF INTELlECTUAL PROPERTY RIGHTS 91-114 (2007); GeRVAIS, supra note 2, at 115-22; UNCTAD-ICTSD, RESOURCE BOOK ON TRIPS AND DEVELOPMENT 118-33 (2005) [hereinafter TRIPS RESOURCE BOOK]. 
Part II begins by tracing the development of Articles 7 and 8 of the TRIPS Agreement. By recounting their historical origins and subsequent developments, this Part shows that, even though only a small amount of the treaty language proposed by lessdeveloped countries was included in the final text of the Agreement, the choice of such language in Articles 7 and 8 may provide less-developed countries with important tools for restoring the balance of the international intellectual property system.

Part III examines the normative content of Articles 7, 8.1, and 8.2 of the TRIPS Agreement. It highlights the interpretations made by WTO panels and the Appellate Body, and the implications of the two declarations adopted during the Fourth WTO Ministerial Conference in Doha. This Part also discusses how the provisions can be interpreted to the advantage of less-developed countries.

Part IV concludes by exploring the five different ways Articles 7 and 8 can be used to facilitate a more flexible interpretation and implementation of the TRIPS Agreement: (1) as a guiding light for interpretation and implementation; (2) as a shield against aggressive demands for increased intellectual property protection; (3) as a sword to challenge provisions that overprotect intellectual property rights or tolerate their abuse; (4) as a bridge to connect the TRIPS regime with other intellectual property or related international regimes; and (5) as a seed for the development of new international intellectual property norms.

\section{ORIGINS AND DEVELOPMENT}

\section{A. The TRIPS Negotiations}

The origins of Articles 7 and 8 of the TRIPS Agreement can be traced back to the Ministerial Conference of the General Agreement on Tariffs and Trade ${ }^{8}$ (GATT) in Punta del Este, Uruguay. ${ }^{9}$ Held in September 1986, this conference took place at a critical point in time when the negotiations between developed and less-developed countries over the revision of the Paris Convention ${ }^{10}$ were deadlocked at WIPO.${ }^{11}$ During that ministerial

8. General Agreement on Tariffs and Trade, Oct. 30, 1947, 61 Stat. A3 (pts. 5 \& 6), 55 U.N.T.S. 188.

9. WATAL, supra note 2, at 21.

10. Paris Convention for the Protection of Industrial Property, Mar. 20, 1883, revised July 14, 1967, 21 U.S.T. 1583, 828 U.N.T.S. 305 [hereinafter Paris Convention].

11. See Peter K. Yu, Currents and Crosscurrents in the International Intellectual Property Regime, 38 LoY. L.A. L. REV. 323, 357-58 (2004). 
conference, the GATT contracting parties set out their negotiating objectives for the new Uruguay Round.

As the Ministerial Declaration stated in a section titled "Trade-related aspects of intellectual property rights, including trade in counterfeit goods":

In order to reduce the distortions and impediments to international trade, and taking into account the need to promote effective and adequate protection of intellectual property rights, and to ensure that measures and procedures to enforce intellectual property rights do not themselves become barriers to legitimate trade, the negotiations shall aim to clarify GATT provisions and elaborate as appropriate new rules and disciplines.

Negotiations shall aim to develop a multilateral framework of principles, rules and disciplines dealing with international trade in counterfeit goods, taking into account work already undertaken in the GATT.

These negotiations shall be without prejudice to other complementary initiatives that may be taken in the World Intellectual Property Organization and elsewhere to deal with these matters.

This section provided the foundation for establishing a new multilateral intellectual property agreement, which eventually became the TRIPS Agreement. Included in the negotiations were four main issues:

(1) substantive standards or norms of IPR [intellectual property right] protection;

(2) procedures under national law for the enforcement of IPR protection;

(3) dispute settlement procedures between parties to any eventual agreement on TRIPs;

(4) the relationship between GATT and other relevant international organizations, including WIPO, concerning TRIPs and the relationship between an eventual agreement in the Uruguay Round and the existing intellectual property conventions. ${ }^{13}$

In the beginning, many less-developed countries naively believed they could use the text of the Punta del Este Declaration to "limit the negotiations primarily on trade in counterfeit goods

12. GATT, Ministerial Declaration on the Uruguay Round of Multilateral Trade Negotiations, pt. I.D, Sept. 20, 1986, 25 I.L.M. 1623, 1626 (1986).

13. David Hartridge \& Arvind Subramanian, Intellectual Property Rights: The Issues in GATT, 22 VAND. J. TRANSNAT'L L. 893, 902 (1989). 
and other such trade-related aspects. ${ }^{\not 14}$ As these countries claimed, the GATT mandate did not allow for the discussion of substantive issues on intellectual property rights. Led by Brazil and India, these countries insisted that only WIPO had the institutional competence to discuss those issues. ${ }^{15}$ However, as Jayashree Watal, a former negotiator for India, pointed out:

This was a misreading not only of the text but also of the writing on the wall. Clearly, the negotiations were aimed not only at clarifying GATT provisions but elaborating, "as appropriate," new rules and disciplines. Significantly, in the very first paragraph, developing countries agreed to take into account "the need to promote effective and adequate protection of IPRs," language that would ultimately lead to the incorporation of minimum standards on a wide range of IPRs in TRIPS. The language in the second paragraph on trade in counterfeit goods was more specific "to develop a multilateral framework of principles, rules and disciplines." The third paragraph only stated that these negotiations were without prejudice to complementary work in WIPO or elsewhere. This language was a concession to the insistence by developing countries that WIPO was the right forum to discuss these issues. By this time, developing countries had conceded that the subject of counterfeit goods could be discussed in GATT. ${ }^{16}$

\section{B. Trade-Related Aspects of IPRs}

To begin with, it is worth considering the various views taken initially by the negotiating parties-or more precisely, the groups of negotiating parties. Consider, for example, the Proposal for Negotiations on Trade-Related Aspects of Intellectual Property Rights ${ }^{17}$ submitted by the United States to the TRIPS Negotiating Group in October 1987. The proposal, which contains a section on objectives, states:

The objective of a GATT intellectual property agreement would be to reduce distortions of and impediments to

14. WATAL, supra note 2 , at 21.

15. Id. at 24 .

16. Id. at 21; accord GERVAIS, supra note 2, at 12 ("One could thus say that the entire TRIPS Agreement, with the possible exception of enforcement provisions destined to curb trade in illicit goods ... rests on the final words in the first paragraph lof the Punta del Este Declaration]: 'and elaborate as appropriate new rules and disciplines." ).

17. Negotiating Group on Trade-Related Aspects of Intellectual Property Rights, Including Trade in Counterfeit Goods [TRIPS Negotiating Group], Suggestion by the United States for Achieving the Negotiating Objective, MTN.GNG/NG11/W/14 (Oct. 20, 1987). 
legitimate trade in goods and services caused by deficient levels of protection and enforcement of intellectual property rights. In order to realize that objective, all participants should agree to undertake the following:

- Create an effective economic deterrent to international trade in goods and services which infringe intellectual property rights through implementation of border measures;

- Recognize and implement standards and norms that provide adequate means of obtaining and maintaining intellectual property rights and provide a basis for effective enforcement of such rights;

-Ensure that such measures to protect intellectual property or enforce intellectual property rights do not create barriers to legitimate trade;

-Extend international notification, consultation, surveillance and dispute settlement procedures to protection of intellectual property and enforcement of intellectual property rights;

-Encourage non-signatory governments to achieve, adopt and enforce the recognized standards for protection of intellectual property and join the agreement. ${ }^{18}$

The United States' proposed language contrasts significantly with the proposals advanced by the European Communities, ${ }^{19}$ which are more modest despite the fact that both parties seemed to have very similar intellectual property-related interests. As stated in the Proposed Guidelines and Objectives submitted by the European Communities to the TRIPS Negotiating Group one year after the first proposal:

In addition to the general considerations [noting the importance of adequate protection of intellectual propertyl, the Community suggests that the negotiations on substantive standards be conducted with the following guidelines in mind:

-they should address trade-related substantive standards in respect of issues where the growing importance of intellectual property rights for international

18. Id. at 3 .

19. See TRIPS Negotiating Group, Guidelines Proposed by the European Community for the Negotiations on Trade-Related Aspects of Intellectual Property Rights, MTN.GNG/NG11/W/16 (Nov. 20, 1987); TRIPS Negotiating Group, Guidelines and Objectives Proposed by the European Community for the Negotiations on Trade Related Aspects of Substantive Standards of Intellectual Property Rights 2-3, MTN.GNG/NG11/W/26 (July 7, 1988) [hereinafter TRIPS Negotiating Group, Guidelines and Objectives]. 
trade requires a basic degree of convergence as regards the principles and the basic features of protection;

- GATT negotiations on trade related aspects of substantive standards of intellectual property rights should not attempt to elaborate rules which would substitute for existing specific conventions on intellectual property matters; contracting parties could, however, when this was deemed necessary, elaborate further principles in order to reduce trade distortions or impediments. The exercise should largely be limited to an identification of and agreement on the principles of protection which should be respected by all parties; the negotiations should not aim at the harmonisation of national laws;

- the GATT negotiations should be without prejudice to initiatives that may be taken in WIPO or elsewhere. Insofar as international or regional conventions and treaties on intellectual property matters exist or insofar as standards have been worked out or are in preparation by WIPO or other international organisations, a GATT Agreement should take account of this work;

- principles agreed upon in the GATT should thus provide a wider basis for the recognition of already existing rules in the field of intellectual property while, at the same time, avoiding ${ }_{20}$ conflict with existing international conventions ....

Of notable interest in this proposal is the European Communities' great deference to the Punta del Este Declaration and its preference for a narrower scope of the new instrument. The proposal stated explicitly that the negotiations "should not attempt to elaborate rules which would substitute for existing specific conventions on intellectual property matters" or prejudice "initiatives that may be taken in WIPO or elsewhere." In its first footnote, the submission made clear its lack of "preference for a 'code' approach."

The European Communities' position was understandable. At that time, many countries, including members of the European Communities and those in the less-developed world, remained uncertain about whether the GATT should include new normative standards for the protection and enforcement of intellectual property rights. ${ }^{23}$ While many countries were

20. TRIPS Negotiating Group, Guidelines and Objectives, supra note 19, at 2.

21. Id.

22. Id. at 2 n.1.

23. Yu, supra note 11 , at 360 . 
sympathetic to offering additional protection against copyright piracy and trademark counterfeiting, others preferred to limit the coverage to a narrower group of issues, such as restrictive and anticompetitive practices of intellectual property rights holders. ${ }^{24}$

Serving as key leaders of the less-developed world, both Brazil and India had been vocal about their opposition to the inclusion of new substantive intellectual property norms in the GATT. Brazil provided one of the earliest proposals, suggesting GATT contracting parties sign the Madrid Agreement for the Repression of False or Deceptive Indications of Source on Goods "as a preliminary to any further discussion on the subject of trade in counterfeit goods. ${ }^{25}$ India did not submit a formal paper to the TRIPS Negotiating Group until two years later.

In July 1989, India submitted a detailed paper expressing its concerns over the objective of the GATT negotiations. Offering a less-developed country's perspective on the negotiations, the paper concluded: "It would ... not be appropriate to establish within the [GATT framework] any new rules and disciplines pertaining to standards and principles concerning the availability, scope and use of intellectual property rights."26 During the meeting of the TRIPS Negotiating Group, India followed up by "ma[king] a fairly detailed intervention," discussing the objectives and principles of the new GATT instrument. ${ }^{27}$ As the GATT Secretariat recounted:

In his statement introducing the Indian paper, the representative of India first referred to recent action by the United States under its trade law and recalled the serious reservations of his delegation about the relevance and utility of the TRIPS negotiations as long as measures of bilateral coercion and threat continued. Subject to this reservation, his delegation submitted the paper circulated as document NG11/W/37, setting out the views of India on this agenda item. At the outset, he emphasised three points. First, India was of the view that it was only the restrictive and anti-competitive practices of the owners of the IPRs that could be considered to be trade-related

24. See, e.g., TRIPS Negotiating Group, Standards and Principles Concerning the Availability Scope and Use of Trade-Related Intellectual Property Rights: Communication from India 19-20, MTN.GNG/NG11/W/37 (July 10, 1989) [hereinafter Communication from India] (communicating India's position that any agreement within the GATT framework should not affect substantive issues of intellectual property rights).

25. TRIPS Negotiating Group, The Madrid Agreement for the Repression of False or Deceptive Indications of Source on Goods: Suggestion by Brazil 1, MTN.GNG/NG11/W/11 (July 9, 1987).

26. Communication from India, supra note 24, at 19-20.

27. TRIPS RESOURCE BOOK, supra note 7, at 121. 
because they alone distorted or impeded international trade. Although India did not regard the other aspects of IPRs dealt with in the paper to be trade-related, it had examined these other aspects in the paper for two reasons: they had been raised in the various submissions made to the Negotiating Group by some other participants; and, more importantly, they had to be seen in the wider developmental and technological context to which they properly belonged. India was of the view that by merely placing the label "trade-related" on them, such issues could not be brought within the ambit of international trade. Secondly, paragraphs $4(\mathrm{~b})$ and 5 of the TNC [Trade Negotiations Committee] decision of April 1989 were inextricably inter-linked. The discussions on paragraph 4(b) should unambiguously be governed by the socio-economic, developmental, technological and public interest needs of developing countries. Any principle or standard relating to IPRs should be carefully tested against these needs of developing countries, and it would not be appropriate for the discussions to focus merely on the protection of the monopoly rights of the owners of intellectual property. Thirdly, he emphasised that any discussion on the intellectual property system should keep in perspective that the essence of the system was its monopolistic and restrictive character. This had special implications for developing countries, because more than 99 per cent of the world's stock of patents was owned by the nationals of the industrialised countries. Recognising the extraordinary rights granted by the system and their implications, international conventions on this subject incorporated, as a central philosophy, the freedom of member States to attune their intellectual property protection system to their own needs and conditions. This freedom of host countries should be recognised as a fundamental principle and should guide all of the discussions in the Negotiating Group.... Substantive standards on intellectual property were really related to socio-economic, industrial and technological development, especially in the case of developing countries. It was for this reason that GATT had so far played only a peripheral role in this area and the international community had established other specialised agencies to deal with substantive issues of IPRs. The Group should therefore focus on the restrictive and anti-competitive practices of the owners of IPRs and evolve standards and principles for their elimination so that international trade was not distorted or impeded by such practices. ${ }^{28}$

28. TRIPS Negotiating Group, Meeting of Negotiating Group of 12-14 July 1989: 
India's position, which was "debated extensively" at the meeting, was supported by other less-developed countries. ${ }^{29}$ These countries maintained their positions even after the European Communities and the United States introduced their draft treaty texts in early $1990 .^{30}$ As late as May 1990 , Chile submitted a document stating that normative intellectual property standards "should in no case be incorporated in the structure of the GATT, but rather ... shall be the subject of an agreement to be administered by WIPO or another organization other than GATT." ${ }^{31}$

As seen from these three very different positions, the development of new minimum standards for the protection and enforcement of intellectual property rights in the GATT was fairly controversial from the beginning of the negotiations. As Lars Anell, chairman of the TRIPS Negotiating Group, admitted: "When the date of the Ministerial Conference to launch the Uruguay Round was fixed it was not clear at all that it would cover intellectual property rights.. ${ }^{32}$ Daniel Gervais also pointed out that the Punta del Este Declaration, despite its scope and potential reach, "shows [in retrospect] how difficult it was to get [the GATT] contracting parties to accept this new subject matter," not to mention the fact that "most of the text states what the future agreement should not do or recasts it in narrow GATT parlance. ${ }^{33}$

\section{The Anell Draft}

By the early 1990 s, it became apparent to all negotiating parties that the inclusion of minimum standards for intellectual property protection and enforcement was inevitable. ${ }^{34}$ Such

Note by the Secretariat 4-5, MTN.GNG/NG11/14 (Sept. 12, 1989).

29. TRIPS RESOURCE BOOK, supra note 7, at 122.

30. See TRIPS Negotiating Group, Communication from Argentina, Brazil, Chile, China, Colombia, Cuba, Egypt, India, Nigeria, Peru, Tanzania and Uruguay, MTN.GNG/NG11/W/71 (May 14, 1990) Thereinafter Communication from Less-Developed Countries] (proposing draft language for the TRIPS Agreement); see also Adronico Oduogo Adede, Origins and History of the TRIPS Negotiations, in TRADING IN KNOWLEDGE 23, 28 (Christophe Bellmann et al. eds., 2003) (noting that this draft text used a two-part structure to "emphasize the part dealing with trade in counterfeit goods while minimizing the part relating to substantive standards on IPRs").

31. TRIPS Negotiating Group, Communication from Chile, MTN.GNG/NG11/W/72 (May 14, 1990).

32. Lars Anell, Foreword to the First Edition of GERVAIS, supra note 2, at vii, vii.

33. GERVAIS, supra note 2, at 11.

34. See Abdulqawi A. Yusuf, TRIPS: Background, Principles and General Provisions, in INTELlectual PROPERTy AND INTERnational TRADE: THE TRIPS AGREement 3, 9 (Carlos M. Correa \& Abdulqawi A. Yusuf eds., 2d ed. 2008) thereinafter 
resignation was also the result of the United States' aggressive strategies toward the hardliner opposition countries, ${ }^{35}$ its successful "divide and conquer" tactics, ${ }^{36}$ the economic crises confronting many of these countries, ${ }^{37}$ and the successful lobbying of the European Communities, Japan, and the United States by global intellectual property industries. ${ }^{38}$ By the time Canada proposed to create a new multilateral trade organization in October 1990, its proposal, along with the less-developed countries' fears of being excluded from such an organization, "effectively ended the debate on the earlier developing country position of WIPO as the appropriate forum for lodging the results of the TRIPS negotiations." ${ }^{39}$

What remained in the negotiations were the details of these new standards and how these standards were to be incorporated into the new Agreement without adversely affecting the protections already put in place by the extant international intellectual property conventions. To expedite the negotiation process and bring the positions of developed and less-developed countries closer to each other, the GATT Secretariat and Chairman Anell prepared what was commonly referred to as the Anell Draft. ${ }^{40}$ This draft was later formalized as the Chairman's Report to the Group of Negotiation on Goods. ${ }^{41}$ As Professor Gervais, who was working at the Secretariat at the time of negotiations, recounted in detail:

In the first few months of 1990 , a number of industrialized countries tabled, with little advance notice, draft legal texts of what they saw as the future TRIPS Agreement. Prior to the tabling of these texts, the discussions had focused on identifying existing norms and possible traderelated gaps therein, but the emerging outline of a possible TRIPS result had essentially been at the level of principles, not legal texts. The draft legal texts, which

INTELLECTUAL PROPERTY AND INTERNATIONAL TRADE] (noting that the submission of draft treaty language by the "Group of 14" developing countries "heralded the acceptance by the developing countries of a GATT-based standard-setting approach in IPRs").

35. See WATAL, supra note 2, at 19. These hardliner countries included Argentina, Brazil, Cuba, Egypt, India, Nicaragua, Nigeria, Peru, Tanzania, and Yugoslavia. Id. at 19 n.17.

36. See Yu, supra note 11, at 412-13.

37. See Peter K. Yu, Access to Medicines, BRICS Alliances, and Collective Action, 34 AM. J.L. \& MED. 345, 365 (2008).

38. See SUSAN K. Sell, PRIvate Power, PUblic LaW 96-120 (2003) (examining the role of the industries in the TRIPS negotiations).

39. WATAL, supra note 2, at 34 .

40. TRIPS RESOURCE BOOK, supra note 7, at xiii.

41. TRIPS Negotiating Group, Status of Work in the Negotiating Group: Chairman's Report to the GNG, MTN.GNG/NG11/W/76 (July 23, 1990). 
emanated from the European Community, the United States, Japan, Switzerland, and Australia, foreshadowed a detailed agreement covering all IP rights then in existence, even the seldom used sui generis protection for computer chips. The proposals also included detailed provisions on the enforcement of those rights before national courts and customs authorities and a provision bringing future TRIPS disputes under the [GATT]/WTO dispute-settlement umbrella. These proposals were far from obvious in light of the limited mandate of the TRIPS negotiating group.

As a reaction, more than a dozen developing countries proposed another "legal" text, much more limited in scope, with few specific normative aspects. They insisted on the need to maintain flexibility to implement economic and social development objectives. In retrospect, some developing countries may feel that the Uruguay Round Secretariat did them a disservice by preparing a "composite" text, which melded all industrialized countries' proposals into what became the "A" proposal, while the developing countries' text became the " $\mathrm{B}$ " text. The final Agreement mirrored the " $\mathrm{A}$ " text. As such, it essentially embodied norms that had been accepted by industrialized countries. The concerns of developing countries were reflected in large part in two provisions-Articles 7 and $8 .^{42}$

The Chairman's Report was later followed up by the text included in the Dunkel Draft-a "take it or leave it" final draft of the TRIPS Agreement advanced by Arthur Dunkel, the GATT's Director-General. That draft constituted the Secretariat's best judgment of what would be acceptable to all of the negotiating parties. ${ }^{43}$ Although Dunkel's approach, and the linkage between trade and intellectual property, was and still is controversial, ${ }^{44}$ his approach proved to be effective. The negotiations quickly concluded. In April 1994, the TRIPS Agreement was adopted

42. Daniel J. Gervais, Intellectual Property, Trade \& Development: The State of Play, 74 FORDHAM L. REV. 505, 507-08 (2005) (footnotes omitted).

43. GeRVAIS, supra note 2, at 24; WATAL, supra note 2, at 37 .

44. As Professor Jagdish Bhagwati noted:

By [the] test of mutual advantage, the [TRIPS Agreement] does not belong to the WTO. It facilitates, even enforces with the aid of trade sanctions, which is in the main a payment by the poor countries (which consume intellectual property) to the rich countries (which produce it). By putting TRIPS into the WTO, in essence we legitimated the use of the WTO to extract royalty payments.

Jagdish Bhagwati, Afterword: The Question of Linkage, 96 AM. J. INT'L L. 126, 127 (2002); see also Daniel J. Gervais, TRIPS 3.0: Policy Calibration and Innovation Displacement, in The DeVElopment AGenda 51, 52 (Neil Weinstock Netanel ed., 2008) ("Some critics opined that intellectual property was not proper subject matter for the WTO."). 
with very minor changes as Annex 1C of the Marrakesh Agreement Establishing the World Trade Organization. ${ }^{45}$

\section{The WTO Panel's Clarification}

Since the TRIPS Agreement entered into force on January 1, 1995, WTO member states have explored the use of Articles 7 and 8 to support their positions. ${ }^{46}$ The divergence of these positions was well reflected in Canada-Patent Protection of Pharmaceutical Products. ${ }^{47}$ In this dispute, the European Communities challenged the regulatory review and stockpiling exceptions in Canadian patent law as violative of the TRIPS Agreement. Calling attention to Articles 7 and 8 of the TRIPS Agreement, Canada contended that these provisions "call for a liberal interpretation of the three conditions stated in Article 30 of the Agreement, so that governments would have the necessary flexibility to adjust patent rights to maintain the desired balance with other important national policies. ${ }^{n 8}$ As the WTO Panel recounted:

In the view of Canada, [the clause "in a manner conducive to social and economic welfare, and to a balance of rights and obligations" in] Article 7... declares that one of the key goals of the TRIPS Agreement was a balance between the intellectual property rights created by the Agreement and other important socio-economic policies of WTO Member governments. Article 8 elaborates the socioeconomic policies in question, with particular attention to health and nutritional policies. ${ }^{49}$

Although the European Communities "did not dispute the stated goal of achieving a balance within the intellectual property rights system between important national policies, ${ }^{, 50}$ it took a very different view of Articles 7 and 8. As the Panel continued:

[I]n the view of the EC, Articles 7 and 8 are statements that describe the balancing of goals that had already taken place in negotiating the final texts of the TRIPS Agreement.

45. See WATAL, supra note 2, at 40-41 (discussing the "finishing touches" to the TRIPS Agreement); Daniel J. Gervais, The TRIPS Agreement and the Doha Round: History and Impact on Economic Development, in 4 INTELLECTUAL PROPERTY AND INFORMATION WEALTH 23, 29 (Peter K. Yu ed., 2007) (“[T]he 1992 text was not extensively modified and became the basis for the TRIPS Agreement adopted at Marrakesh on April 15, 1994.”).

46. See TRIPS RESOURCE BOOK, supra note 7, at 119 ("Articles 7 and 8 have been invoked by Members to support rather different views of the purposes of TRIPS.").

47. Panel Report, Canada-Patent Protection of Pharmaceutical Products, WT/DS114/R (Mar. 17, 2000).

48. Id. II 7.24 .

49. Id.

50. Id. II 7.25 . 
According to the EC, to view Article 30 as an authorization for governments to "renegotiate" the overall balance of the Agreement would involve a double counting of such socioeconomic policies. In particular, the EC pointed to the last phrase of Article 8.1 requiring that government measures to protect important socio-economic policies be consistent with the obligations of the TRIPS Agreement. The EC also referred to the provisions of first consideration of the Preamble and Article 1.1 as demonstrating that the basic purpose of the TRIPS Agreement was to lay down minimum requirements for the protection and enforcement of intellectual property rights. ${ }^{51}$

In the end, the Panel found Canada's position a little more convincing and struck a compromise between the two positions by allowing for "certain adjustments" while preventing "a renegotiation of the basic balance of the Agreement. ${ }^{, 52}$ As the panel declared:

Article 30's very existence amounts to a recognition that the definition of patent rights contained in Article 28 would need certain adjustments. On the other hand, the three limiting conditions attached to Article 30 testify strongly that the negotiators of the Agreement did not intend Article 30 to bring about what would be equivalent to a renegotiation of the basic balance of the Agreement. Obviously, the exact scope of Article 30's authority will depend on the specific meaning given to its limiting conditions. The words of those conditions must be examined with particular care on this point. Both the goals and the limitations stated in Articles 7 and 8.1 must obviously be borne in mind when doing so as well as those of other provisions of the TRIPS Agreement which indicate its object and purposes. ${ }^{53}$

Some commentators were disappointed by the Panel's finding, which they argued would perpetuate the unfairness of the TRIPS Agreement and take away the member states' needed discretion in developing their public policies. ${ }^{54}$ Although these

51. Id. (emphasis added).

52. Id. II 7.26 .

53. Id.

54. See, e.g., Denis Borges Barbosa et al., Slouching Towards Development in International Intellectual Property, 2007 MICH. ST. L. REV. 71, 113 (suggesting that WTO adjudicative bodies should not "assum[e] that the balance has already been struck with respect to each separate part of the treaty," but rather should "recalibrate the balance of principles with respect to each treaty provision as applied to the specific legal issue in dispute"); Robert Howse, The Canadian Generic Medicines Panel-A Dangerous Precedent in Dangerous Times, 3 J. WORLD INTELL. PROP. 493, 493-94, 496 (2000) (criticizing the WTO Panel for "ignor[ing the] words about balance and mutual advantage [as stated in 
reactions are understandable, judicial activism and loose interpretation in WTO decisions can cut both ways. If the Panel allowed a party to use Articles 7 and 8 to renegotiate the basic balance of the TRIPS Agreement, later panels would have to allow other parties to do the same. In the end, it is questionable whether a more activist approach would help less-developed countries more than it would hurt them (considering the fact that developed countries hitherto have brought most of the complaints filed with the WTO Dispute Settlement Body). ${ }^{55}$

It is nevertheless worth noting that neither the Appellate Body nor the WTO panels have made any definitive interpretation and application of Articles 7 and 8 of the TRIPS Agreement. ${ }^{56}$ As Carlos Correa pointed out, the Panel in Canada-Patent Protection of Pharmaceutical Products "avoided elaboration of the content and implications of Articles 7 and 8.1, despite the specific reference that the parties made thereto in their submissions. ${ }^{" 57}$ In a later case, Canada-Term of Patent Protection, the Appellate Body also acknowledged that it has yet to determine "the applicability of Article 7 or Article 8 of the TRIPS Agreement in possible future cases with respect to measures to promote the policy objectives of the WTO Members that are set out in those Articles. ${ }^{, 58}$ According to the Appellate Body, "[t]hose Articles still await appropriate interpretation."

\section{E. The Doha Fortifications}

During the Doha Ministerial, WTO member states adopted two very important documents: (1) the Doha Ministerial

Article 7 and] interpreting the patent provisions of the TRIPS Agreement largely from the perspective of intellectual property rights holders," and for being "only interested in how much the rights holder might lose, not in how much society might gain, from a given exception"); Ruth L. Okediji, Public Welfare and the Role of the WTO: Reconsidering the TRIPS Agreement, 17 EMORY INT'L L. REV. 819, 914-15 (2003) (expressing disappointment that WTO panels, despite focusing on the purpose and objective of the TRIPS Agreement and the context of the negotiations, "have interpreted the provisions almost solely in light of the economic expectations of the private right holders").

55. See William J. Davey, The WTO Dispute Settlement System: The First Ten Years, 8 J. INT'L ECON. L. 17, 17-18 (2005) (“'TThe first half of [the first ten years of operation of the WTO dispute settlement process]-from 1995 through 1999-was characterized by extensive use of the system by the United States initially, and later by the EU.").

56. See Barbosa et al., supra note 54, at 98 ("The balancing role of articles 7 and 8 has not received full support in the WTO case law. The WTO Appellate Body analysis in Canada-Patent Protection of Pharmaceutical Products ... is not definitive ....").

57. CORREA, supra note 7, at 102.

58. Appellate Body Report, Canada-Term of Patent Protection, II 101, WT/DS170/AB/R (Sept. 18, 2000).

59. Id. 
Declaration (Ministerial Declaration) ${ }^{60}$ and (2) the Declaration on the TRIPS Agreement and Public Health (Doha Declaration) ${ }^{61}$ Both documents strongly reinforced the objectives and principles set forth in Articles 7 and 8 of the TRIPS Agreement.

Paragraph 19 of the Ministerial Declaration concerned the work program conducted by the TRIPS Council, including "the review of Article 27.3(b) [of the TRIPS Agreement], the review of the implementation of the TRIPS Agreement under Article 71.1 and the work foreseen pursuant to Paragraph 12 of this Declaration," which focused on implementation-related issues and concerns. ${ }^{62}$ The Declaration explicitly "instruct[ed] the Council ... to examine, inter alia, the relationship between the TRIPS Agreement and the Convention on Biological Diversity, the protection of traditional knowledge and folklore, and other relevant new developments raised by Members pursuant to Article 71.1." [the work outlined in this paragraph], the TRIPS Council shall be guided by the objectives and principles set out in Articles 7 and 8 of the TRIPS Agreement and shall take fully into account the development dimension." ${ }^{64}$

Compared to the Ministerial Declaration, the Doha Declaration focused more specifically on the interplay between intellectual property protection and the protection of public health. The first two paragraphs of the Declaration explicitly "recognize[d] the gravity of the public health problems afflicting many developing and least-developed countries, especially those resulting from HIV/AIDS, tuberculosis, malaria and other epidemics... [and] stress[ed] the need for the [TRIPS Agreement] to be part of the wider national and international action to address these problems."

Paragraph 4 of the Doha Declaration then stated that member states "agree that the TRIPS Agreement does not and should not prevent Members from taking measures to protect public health." ${ }^{\prime 66}$ The language used in this paragraph strongly resembled the language provided by less-developed countries

60. World Trade Organization, Ministerial Declaration of 14 November 2001, WT/MIN(01)/DEC/1, 41 I.L.M. 746 (2002) [hereinafter Ministerial Declaration].

61. World Trade Organization, Declaration on the TRIPS Agreement and Public Health, WT/MIN(01)/DEC/2, 41 I.L.M. 755 (2002) [hereinafter Doha Declaration].

62. Ministerial Declaration, supra note 60, II $12,19$.

63. Id. II 19.

64. Id.

65. Doha Declaration, supra note 61, II 1-2.

66. Id. II 4. 
before the ministerial conference. As stated in their submission to the TRIPS Council:

In Article 8, the TRIPS Agreement affirms that Members may adopt measures to protect public health, among other overarching public policy objectives, such as nutrition and socio-economic and technological development. Any interpretation of the provisions of the Agreement should take into account the principles set forth in Article 8. The reading of such provision should confirm that nothing in the TRIPS Agreement will prevent Members from adopting measures to protect public health, as well as from pursuing the overarching policies defined in Article 8. ${ }^{67}$

Paragraph 4 of the Declaration further noted that the TRIPS Agreement "can and should be interpreted and implemented in a manner supportive of WTO Members' right to protect public health and, in particular, to promote access to medicines for all. ${ }^{, 68}$

Finally, the Declaration underscored the various "flexibilities" reserved to all WTO member states under the TRIPS Agreement, which include the following:

(a) In applying the customary rules of interpretation of public international law, each provision of the TRIPS Agreement shall be read in the light of the object and purpose of the Agreement as expressed, in particular, in its objectives and principles.

(b) Each Member has the right to grant compulsory licences and the freedom to determine the grounds upon which such licences are granted.

(c) Each Member has the right to determine what constitutes a national emergency or other circumstances of extreme urgency, it being understood that public health crises, including those relating to HIV/AIDS, tuberculosis, malaria and other epidemics, can represent a national emergency or other circumstances of extreme urgency.

(d) The effect of the provisions in the TRIPS Agreement that are relevant to the exhaustion of intellectual property rights is to leave each Member free to establish its own regime for such exhaustion without challenge, subject to the

67. Council for Trade-Related Aspects of Intellectual Property Rights, Submission by the African Group, Barbados, Bolivia, Brazil, Cuba, Dominican Republic, Ecuador, Honduras, India, Indonesia, Jamaica, Pakistan, Paraguay, Philippines, Peru, Sri Lanka, Thailand and Venezuela, II 22, IP/C/W/296 (June 29, 2001) [hereinafter Doha Submission].

68. Doha Declaration, supra note 61, II 4. 
MFN and national treatment provisions of Articles 3 and $4 .{ }^{69}$

\section{F. An Elevated Legal Status?}

Taken together, the two declarations have put the relationship between the TRIPS Agreement and the protection of public health in a special light. Nevertheless, their legal effect on Articles 7 and 8 remains unclear. As Professor Correa pointed out:

There are different possible interpretations for [Paragraph 4 of the Doha Declaration]. On the one hand, it may be viewed as a statement of fact rather than a rebalancing of the Agreement. On the other, it may be regarded as an indication that in cases where there is conflict, IPRs should not be an obstacle to the realization of public health. ${ }^{70}$

Those who view the Declaration as a statement of fact are unlikely to impute to Articles 7 and 8 any new or elevated legal status. ${ }^{11}$ In fact, one could make a strong argument that the Doha Declaration was a mere restatement of Article 31.1 of the Vienna Convention, which stipulates that "[a] treaty shall be interpreted in good faith in accordance with the ordinary meaning to be given to the terms of the treaty in their context and in the light of its object and purpose." ${ }^{\text {22 }}$ Since the WTO panels and the Appellate Body began their operations, they have embraced the provision as part of the customary rules of interpretation as required by the Dispute Settlement Understanding. ${ }^{73}$ Moreover, it is important not to overstate the impact of the Doha negotiations.

69. Id. II 5.

70. CORREA, supra note 7, at 105 (footnote omitted).

71. See GERVAIS, supra note 2, at $\mathbf{1 2 0}$ (noting that the Doha Declaration "is unlikely to formally change the legal status of [Articles 7 and 8]").

72. Vienna Convention on the Law of Treaties art. 31.1, May 23, 1969, 1155 U.N.T.S. 331 [hereinafter Vienna Convention] (emphasis added); see also TRIPS RESOURCE BOOK, supra note 7, at 132 ("Paragraph 5(a) [of the Doha Declaration] states an interpretative principle that has already been enunciated by the panel in the Canada-Generics case, and that would already be understood by operation of Article 31 of the Vienna Convention on the Law of Treaties."). For a detailed discussion of the use of the Vienna Convention in TRIPS disputes by WTO panels and the Appellate Body, see Susy Frankel, WTO Application of "the Customary Rules of Interpretation of Public International Law" to Intellectual Property, 46 VA. J. INT'L L. 365, 384-90 (2006); Daya Shanker, The Vienna Convention on the Law of Treaties, the Dispute Settlement System of the WTO and the Doha Declaration on the TRIPs Agreement, 36 J. WORLD TRADE 721, 723-36 (2002).

73. Understanding on Rules and Procedures Governing the Settlement of Disputes, Apr. 15, 1994, Marrakesh Agreement Establishing the World Trade Organization, Annex 2, Legal Instruments-Results of the Uruguay Round, 33 I.L.M. 1125 (1994) [hereinafter Dispute Settlement Understanding]. 
As Susy Frankel noted:

Doha may have rightfully curtailed attempts to suggest meanings other than that each Member may determine what is a "national emergency," but the idea that the declaration provides any clarity to the already clear words appears to be a politically convenient overstatement that turns a blind eye to the principles of treaty interpretation. ${ }^{74}$

By contrast, those who consider the Declaration an attempt to rebalance the TRIPS Agreement are likely to point to the fact that the trade ministers of the WTO member states, via the Doha Declaration, "agree[d] that the TRIPS Agreement does not and should not prevent Members from taking measures to protect public health." ${ }^{75}$ Notably, Paragraph 4 of the Declaration did not repeat the phrase "adopt measures necessary to protect public health" as used in Article 8.1 of the TRIPS Agreement. ${ }^{76}$ The necessity requirement was conspicuously omitted.

If such an omission is insufficient, Paragraph 4 uses the word "agree," while the other paragraphs of the Declaration use words such as "recognize," "stress," "affirm," and "reaffirm." As noted in the UNCTAD-ICTSD Resource Book on TRIPS and Development (TRIPS Resource Book):

The first important point regarding [Paragraph 4] is that it is stated in the form of an agreement (i.e., "we agree"). Since this statement was adopted by consensus of the Ministers, and since the operative language is in the form of an agreement, this may be interpreted as a "decision" of the Members under Article IX.1 of the WTO Agreement. Although paragraph 4 is not an "interpretation" in the formal sense [because] it was not based on a recommendation of the TRIPS Council pursuant to Article IX.2 of the WTO Agreement, a decision that states a meaning of the Agreement should be considered as a very close approximation of an interpretation and, from a functional standpoint, may be indistinguishable. ${ }^{78}$

Indeed, the word choice in this paragraph is identical to that of Paragraph 7 of the Declaration-the provision that extended the deadline for least-developed countries to protect

74. Frankel, supra note 72, at 401.

75. Doha Declaration, supra note 61, Il 4.

76. Id.; TRIPS Agreement, supra note 1, art. 8.1 (emphasis added).

77. Compare Doha Declaration, supra note 61, I 4 (using the word "agree" in addition to "affirm" and "reaffirm"), with id. आI 1, 3, 5, 6 (using the word "recognize"), id. If 2 ("stress"), and id. IT 7 ("reaffirm").

78. TRIPS RESOURCE BOOK, supra note 7, at 131. 
pharmaceuticals through January $1,2016 .{ }^{79}$ Because those two paragraphs are the only paragraphs in the whole declaration that use the word "agree," Paragraph 4 should be given the same legal effect. ${ }^{80}$ After all, there is no denial that the WTO member states have reached an agreement over the extension of the deadline for least-developed countries in Paragraph 7.

Regardless of whether the Doha Declaration restates or renegotiates the balance in the TRIPS Agreement, the explicit inclusion of Articles 7 and 8 in the Ministerial Declaration is likely to have a significant impact on the work of the TRIPS Council. This is particularly true when Paragraph 19 of the Ministerial Declaration is read together with Paragraph 4 of the Doha Declaration. ${ }^{81}$ The two Doha documents are also likely to have additional impact on decisions reached by WTO panels and the Appellate Body. As Professor Gervais noted:

The importance accorded to these Articles in the Doha negotiations ... may lead a panel to take a longer look at how these provisions should be interpreted in the context of the Agreement as a whole, especially with respect to the need for "balance." A possible practical impact of the Doha insistence of [Articles] 7 and 8 may serve as a basis for the interpretation of certain provisions of the Agreement. ${ }^{82}$

Moreover, Article 31.3 of the Vienna Convention states that "[t]here shall be taken into account, together with the context... any subsequent agreement between the parties regarding the interpretation of the treaty or the application of its provisions." ${ }^{83}$ Although it is arguable whether the Doha documents would constitute a subsequent agreement, WTO panels and the Appellate Body are likely to take the documents into account as subsequent developments. After all, as Professor Frankel pointed out, the WTO panel in United States-Section

79. See Doha Declaration, supra note 61, I 7.

80. It is worth noting, however, that the WTO member states further "instruct[ed] the Council for TRIPS to take the necessary action to give effect to this pursuant to Article 66.1 of the TRIPS Agreement." Doha Declaration, supra note 61, II 7. The TRIPS Council did so in its decision of June 27, 2002. Council for Trade-Related Aspects of Intellectual Property Rights, Extension of the Transition Period Under Article 66.1 of the TRIPS Agreement for Least-Developed Country Members for Certain Obligations with Respect to Pharmaceutical Products, IP/C/25 (June 27, 2002).

81. See Ministerial Declaration, supra note 60, If 19 (instructing the TRIPS Council to implement the Agreement in accordance with the objectives and principles of Articles 7 and 8); Doha Declaration, supra note 61, I 4 (affirming "the right of WTO members to use, to the full, the provisions in the TRIPS Agreement, which provide flexibility for this purpose").

82. GERVAIS, supra note 2, at 120 (footnote omitted).

83. Vienna Convention, supra note 72, art. 31.3(a). 
110(5) of the U.S. Copyright Act considered the WIPO Copyright Treaty as a subsequent development even though it has neither come into force nor been ratified by either party. ${ }^{84}$ Based on an extension of that logic, one could make a strong argument that the Doha documents should constitute a subsequent agreement. ${ }^{85}$

\section{NORMATIVE CONTENT}

\section{A. Article 7}

Article 7 delineates the objectives of the TRIPS Agreement. The article provides:

The protection and enforcement of intellectual property rights should contribute to the promotion of technological innovation and to the transfer and dissemination of technology, to the mutual advantage of producers and users of technological knowledge and in a manner conducive to social and economic welfare, and to a balance of rights and obligations. $^{86}$

While the first three objectives-technological innovation, transfer and dissemination of technology, and the production and use of technological knowledge-focus mainly on technological development and may not affect all forms of intellectual property rights, the latter two have a much broader focus and cover virtually all forms of intellectual property rights.

The origin and focus of these two objectives become clearer when they are viewed in light of the negotiating history of Article 7. In the beginning of the TRIPS negotiations, the discussion focused primarily on the interests of developed countries-that is, to promote the contributions of authors and inventors. ${ }^{87}$ As Frederick Abbott pointed out, the promotion of these contributions can be seen as the protection of "First World

84. See Frankel, supra note 72, at 413-14.

85. Other commentators have made a similar point. E.g., Yusuf, supra note 34, at 15 ("The Doha Declaration may be considered to constitute a subsequent agreement between the parties to a treaty regarding its interpretation in accordance with [Article 31.3(a)] of the Vienna Convention on the Law of Treaties."); Henning Grosse Ruse-Khan, A Comparative Analysis of Policy Space in WTO Law 42 (Max Planck Inst. for Intellectual Prop., Competition \& Tax Law, Research Paper No. 08-02, 2008), available at http://ssrn.com/abstract=1309526 "Formally, the Declaration on TRIPS and Public Health can be considered as a source for interpreting TRIPS equivalent to treaty 'context' as it amounts to a 'subsequent agreement between the parties regarding the interpretation of the treaty or the application of its provisions' under [Article 31.3(a) of the Vienna Convention].").

86. TRIPS Agreement, supra note 1, art. 7 (emphasis added).

87. See WATAL, supra note 2, at 22-23. 
assets"-assets that were of marginal interest to the lessdeveloped world. ${ }^{88}$

Although less-developed countries initially resisted the inclusion of new substantive standards for the protection and enforcement of intellectual property rights in the GATT, they soon realized that they were fighting a losing battle. As a result, they began to insist on linking intellectual property protection to the promotion of social, economic, and technological development. ${ }^{89}$ Deeply aware of their weakness in generating new science and technology, they feared that stronger intellectual property protection "would give too much power to title-holders and limit access to, and transfer of, technology to those countries, ${ }^{, 90}$ and, in GATT parlance, would result in distortions or impediments to trade in legitimate goods. ${ }^{91}$ They were also worried that their interests would be relegated to secondary status, if those interests would be respected at all. ${ }^{92}$

When the European Communities submitted its draft text in March $1990,{ }^{93}$ followed by the United States two months later, ${ }^{94}$ less-developed countries had no choice but to respond by

88. See Frederick M. Abbott, Protecting First World Assets in the Third World: Intellectual Property Negotiations in the GATT Multilateral Framework, 22 VAND. J. TRANSNATLL L. 689 (1989).

89. See Yusuf, supra note 34, at 10 ("The inclusion of provisions on objectives and principles in the TRIPS Agreement was prompted by the developing countries' insistence on the link between the protection of IPRs and the promotion of social and economic and technological development.").

90. CORREA, supra note 7, at 91 .

91. See Frankel, supra note 72, at 380 ("The preamble [of the TRIPS Agreement] sets the scene of 'desiring to reduce distortions and impediments to international trade,' and ... is a reminder that protecting intellectual property rights is legitimate, but that protection must not become a barrier to legitimate trade."). As Professor Frankel pointed out, "[o]ne of the difficulties is that 'desiring to reduce distortions and impediments to international trade' is not necessarily the same object and purpose as 'effective and adequate' intellectual property laws and the rationales of protecting intangible intellectual property rights." Id. at 391 (quoting TRIPS Agreement, supra note 1, pmbl. recital 1).

92. See TRIPS RESOURCE BOOK, supra note 7, at 119.

Developing country Members have expressed considerable concern that only one side of the Agreement's objectives are pursued by developed Members, these being the objectives relating to the protection of technology 'assets,' while the stated objectives 'that the protection and enforcement of intellectual property rights should contribute to the promotion' of transferring technology and actively promoting developmental interests are relegated to a secondary, and perhaps even illusory, status. Id.

93. TRIPS Negotiating Group, Draft Agreement on Trade-Related Aspects of Intellectual Property Rights, MTN.GNG/NG11/W/68 (Mar. 29, 1990).

94. TRIPS Negotiating Group, Draft Agreement on the Trade-Related Aspects of Intellectual Property Rights: Communication from the United States, MTN.GNG/NG11/W/70 (May 11, 1990). 
advancing their own text. ${ }^{95}$ As Abdulqawi Yusuf recounted, some of the provisions in this text "were either directly based on or inspired by those of the Draft International Code of Conduct on the Transfer of Technology which was negotiated under the auspices of UNCTAD [the United Nations Conference on Trade and Development] but was never adopted as an international instrument. ${ }^{96}$ Article 2 of the draft, which provides the normative principles, states:

(1) Parties recognize that intellectual property rights are granted not only in acknowledgement of the contributions of inventors and creators, but also to assist in the diffusion of technological knowledge and its dissemination to those who could benefit from it in a manner conducive to social and economic welfare and agree that this balance of rights and obligations inherent in all systems of intellectual property rights should be observed.

(2) In formulating or amending their national laws and regulations on IPRs, Parties have the right to adopt appropriate measures to protect public morality, national security, public health and nutrition, or to promote public interest in sectors of vital importance to their socioeconomic and technological development.

(3) Parties agree that the protection and enforcement of intellectual property rights should contribute to the promotion of technological innovation and enhance the international transfer of technology to the mutual advantage of producers and users of technological knowledge.

(4) Each Party will take the measures it deems appropriate with a view to preventing the abuse of intellectual property rights or the resort to practices which unreasonably restrain trade or adversely affect the international transfer of technology. Parties undertake to consult each other and to co-operate in this regard. ${ }^{97}$

The text was eventually adopted as Articles 7 and 8 of the TRIPS Agreement. While subparagraphs (1) and (3) found their way to Article 7, the rest became Article 8. The italicized text, which was omitted in the final version of Article $7,{ }^{98}$ made clear the concerns

95. Communication from Less-Developed Countries, supra note 30.

96. Yusuf, supra note 34, at $10 \mathrm{n} .18$ (citation omitted). For discussions on the Draft International Code of Conduct, see generally INTERNATIONAL TECHNOLOGY TRANSFER (Surendra J. Patel et al. eds., 2001); Yu, supra note 4, at 493-505.

97. Communication from Less-Developed Countries, supra note 30, art. 2 (emphasis added).

98. TRIPS Agreement, supra note 1, art. 7. 
of the less-developed world. Those concerns also explain why the first three objectives of Article 7 focus significantly on technology-related intellectual property rights. As Professor Correa surmised:

This imbalance [in the focus] is possibly attributable to developing countries' preoccupation about the impact of higher standards of IPR protection on the access to innovations and the products and services derived therefrom. Negotiations on issues not directly related to access to and use of technology were overall less controversial between the North and the South, while they often created considerable tensions between developed countries themselves. ${ }^{99}$

It is worth noting that the first provision of the B text supplied the last two objectives, while the third provision provided the first three objectives.

From the standpoint of treaty interpretation, it is important to point out that Article 7 is a "should" provision, as opposed to a "shall" provision. ${ }^{100}$ Although this word choice has led some industry groups and commentators to argue that the provision is "mere hortatory," ignored. In fact, according to Professor Gervais, "[t]he fact that a provision of this nature is contained in the body of the agreement, and not in the preamble, would seem to heighten its status. ${ }^{102}$ His view is further supported by the Appellate Body in United States-Standards for Reformulated and Conventional Gasoline, which stated that treaty interpreters should "take

99. CORREA, supra note 7, at 92 (footnote omitted).

100. GERVAIS, supra note 2 , at 116 .

101. See CORREA, supra note 7, at 93 ('Some observers have read 'should' to mean that Article 7 is a mere hortary [sic] provision, the interpretative value of which is equivalent to that of any preambular provision."); JACQUES J. GORLIN, AN ANALYSIS OF THE Pharmaceutical-Related Provisions OF THE WTO TRIPS (INTEllectual PROPERTY) AGREEMENT 16 (1999) (stating that "[a]ccording to United States and EC negotiators, the language of Article 7 is hortatory and does not have any operational significance" and that Article 8 "was viewed by developed country negotiators throughout most of the negotiations as being non-operational and hortatory" (citing interviews with Mike Kirk and Peter Carl)); Margaret Chon, Intellectual Property and the Development Divide, 27 CARDOZO L. REV. 2821, 2843 (2006) (“'T]he language referencing development in TRIPS is not mandatory, but rather hortatory ....").

102. GERVAIS, supra note 2, at 116. As Professor Correa has stated:

[T] he negotiating parties had the option to include the provision in the Preamble but they did it in Part I of the Agreement, under the heading 'General provisions and basic principles.' The interpreter cannot disregard this choice... [which] indicates that these provisions are to be systematically applied in the implementation and interpretation of the Agreement."

CORREA, supra note 7, at 93 (footnote omitted). 
adequate account of the words actually used" by the covered agreement. $^{103}$

Moreover, the TRIPS Agreement represents a compromise between the two texts advanced by the developed and lessdeveloped worlds. While the objectives and principles in the A text found their way to the Preamble, the B text provided the language for Articles 7 and 8 of the TRIPS Agreement (as well as the Preamble). As the TRIPS Resource Book reminded us:

It is significant that the developing country proposal for objectives and principles became operative provisions of TRIPS (i.e., Articles 7 and 8), while the largely developed country proposals set out in the Annex were reflected in the more general statement of intent (i.e., the Preamble). Because articles of a treaty are intended to establish rights and obligations, Articles 7 and 8 should carry greater weight in the process of implementation and interpretation. ${ }^{104}$

Thus, the strongest argument developed countries and their intellectual property industries could make based on the plain meaning of the Agreement and the context provided by the TRIPS negotiation history is that Article 7 "may not be used to reduce the scope of 'shall' or equivalents thereof in other Articles," assuming that the Doha documents did not elevate its legal status. ${ }^{105}$ However, because Article 7 is included in the text of the Agreement, it should be given greater weight than the treaty's preambular provisions. After all, the latter were primarily "designed to establish a definitive record of the intention or purpose of the parties in entering into the agreement. ${ }^{106}$

From the standpoint of policy development, Article 7 is also rather important. Highlighting the many public interest objectives of the TRIPS Agreement, the provision "makes it clear that IPRs are not an end in themselves." ${ }^{107}$ As less-developed countries declared in their submission to the TRIPS Council before the Doha Ministerial, "Article 7 . . clearly establishes that the protection and enforcement of intellectual property rights do

103. Appellate Body Report, United States-Standards for Reformulated and Conventional Gasoline, pt. III.B, WT/DS2/AB/R (Apr. 29, 1996); accord TRIPS RESOURCE BooK, supra note 7, at 118 ("A general principle of treaty interpretation is that terms are presumed not to be surplus. Words are in a treaty for a reason and should be given their ordinary meaning in its context." (footnote omitted)).

104. TRIPS RESOURCE BOOK, supra note 7, at 123-24.

105. GERVAIS, supra note 2 , at 116 .

106. TRIPS RESOURCE BOOK, supra note 7, at 2 .

107. Id. at 125-26. 
not exist in a vacuum. They are supposed to benefit society as a whole and do not aim at the mere protection of private rights." ${ }^{108}$

Likewise, the final report of the U.K. Commission on Intellectual Property Rights states that intellectual property rights should be regarded "as instruments of public policy which confer economic privileges on individuals or institutions solely for the purposes of contributing to the greater public good," and that the conferred privileges should be "a means to an end, not an end in itself." Such an emphasis is important "because interest groups often lose sight of the basic mission of the WTO which, as stated in the preamble of the WTO Agreement, is to promote trade and economic development, not to protect the interests of particular private IPR-holding interest groups."110

The use of the word "should" in Article 7 further reminds member states that stronger intellectual property protection does not necessarily lead to more innovation, dissemination of knowledge, or the transfer of technology. ${ }^{111}$ To date, economists have provided an abundance of empirical studies to demonstrate the ambiguous relationship intellectual property protection has with economic development, technology transfer, and foreign direct investment (FDI). ${ }^{112}$ For example, Claudio Frischtak states that a country's overall investment climate is often more influential on FDI decisions than the strength of intellectual

108. Doha Submission, supra note $67, \mathbb{I} 18$.

109. COMM'N ON INTELleCtUAL PROP. Rights, INTEgRATING INTELLECTUAL PROPERTY RIGHTS AND DEVELOPMENT POLICY 6 (2002). As Professor Ricolfi has stated:

A closer reading of TRIPs ... shows that IP protection and enforcement are seen as means rather than ends in themselves both because the larger ends encompass freedom of trade ... and because the international community is committed to taking into account other non-trade and non-IP factors while shaping IP protection.

Marco Ricolfi, Is There an Antitrust Antidote Against IP Overprotection Within TRIPs?, 10 MARQ. INTELL. PROP. L. REV. 305, 326 (2006).

110. TRIPS RESOURCE BOOK, supra note 7, at 10.

111. CORREA, supra note 7, at 97; see also id. at 99 ("IPRs are but one of many factors-and arguably not the most important factor-that affect cross-border flows of technology."). Similarly, in their submission to the TRIPS Council during the Doha negotiations, less-developed countries declared:

Article 7 states that the protection and enforcement of intellectual property rights "should" contribute to the aforementioned objectives. Such language stems from a recognition by Members that the mere existence and the exercise of IPRs, such as patents, do not necessarily result in the fulfilment of the objectives of the Agreement.

Doha Submission, supra note 67, II 19 (emphasis omitted).

112. For a review of the economic literature discussing this ambiguous relationship, see generally Peter K. Yu, Intellectual Property, Economic Development, and the China Puzzle, in InTellectual Property, Trade and Development 173, 176-80 (Daniel J. Gervais ed., 2007). 
property protection it offers. ${ }^{113}$ Carsten Fink and Keith Maskus observed that "[a] poor country hoping to attract inward FDI would be better advised to improve its overall investment climate and business infrastructure than to strengthen its patent regime sharply, an action that would have little effect on its own."114 Professor Maskus further stated that, if stronger intellectual property protection always led to more FDI, "recent FDI flows to developing economies would have gone largely to sub-Saharan Africa and Eastern Europe ... [rather than] China, Brazil, and other high-growth, large-market developing economies with weak IPRs." 115

Furthermore, the five objectives in Article 7 provide useful guidance to those involved in implementing the TRIPS Agreement. For example, the first three objectives-technological innovation, the transfer and dissemination of technology, and the production and use of technological knowledge-provide support to those provisions of the TRIPS Agreement that outline the obligations of developed countries to promote technology transfer, technical cooperation, and legal assistance in developing and least-developed countries. ${ }^{116}$ Article 66 of the TRIPS Agreement states that "[d]eveloped country Members shall provide incentives to enterprises and institutions in their territories for the purpose of promoting and encouraging technology transfer to least-developed country Members in order to enable them to create a sound and viable technological base." ${ }^{117}$ Article 67, entitled "Technical Cooperation," further provides:

In order to facilitate the implementation of this Agreement, developed country Members shall provide, on request and on mutually agreed terms and conditions, technical and financial cooperation in favour of developing and leastdeveloped country Members. Such cooperation shall include assistance in the preparation of laws and regulations on the

113. See Claudio R. Frischtak, Harmonization Versus Differentiation in Intellectual Property Right Regimes, in Global DIMENSIONS OF INTELLECTUAL PROPERTY RightS IN SCIENCE AND TECHNOLOGY 89, 99-100 (Mitchel B. Wallerstein et al. eds., 1993) (noting that the nature of a country's intellectual property regime was traditionally a secondary concern in a company's FDI decision).

114. Carsten Fink \& Keith E. Maskus, Why We Study Intellectual Property Rights and What We Have Learned, in INTELLECTUAL PROPERTY AND DEVELOPMENT 1, 7 (Carsten Fink \& Keith E. Maskus eds., 2005).

115. Keith E. Maskus, The Role of Intellectual Property Rights in Encouraging Foreign Direct Investment and Technology Transfer, 9 DUKE J. COMP. \& INT'L L. 109, 12829 (1998) (footnotes omitted).

116. See TRIPS RESOURCE BOOK, supra note 7, at 126 ("[Article 7] provides support for efforts to encourage technology transfer, with reference also to Articles 66 and $67 . "$ ).

117. TRIPS Agreement, supra note 1, art. 66. 
protection and enforcement of intellectual property rights as well as on the prevention of their abuse, and shall include support regarding the establishment or reinforcement of domestic offices and agencies relevant to these matters, including the training of personnel. ${ }^{118}$

The third objective highlights the equal importance of both producers and users of technological knowledge. It therefore makes a strong case that exceptions and limitations in the TRIPS Agreement should be treated as important as the rights provided in the Agreement-an argument commentators have made with respect to exceptions and limitations in the domestic intellectual property system. ${ }^{119}$ To some extent, Article 7 paves the way for the development of future exceptions and limitations, which can be used to restore the balance of the international intellectual property system. This objective is particularly important to lessdeveloped countries, which "are largely users of technologies produced abroad." 20 Because these countries tend to have many more consumers than producers, Article 7 will greatly benefit them when users are broadly "interpreted as encompassing final consumers as well as producers of goods and services that utilize technological knowledge."121

The last two objectives underscore the need to take account of the member states' "social and economic welfare" and the need to develop "a balance of rights and obligations." As the TRIPS Resource Book declared:

Article 7 makes clear that TRIPS negotiators did not mean to abandon a balanced perspective on the role of intellectual property in society. TRIPS is not intended only to protect the interests of right holders. It is intended to strike a balance that more widely promotes social and economic welfare. ${ }^{123}$

Although there is a tendency for policymakers to strike a balance within the TRIPS regime, Article 7 mentions broadly "[t]he protection and enforcement of intellectual property rights." ${ }^{124}$ The provision therefore anticipates further balancing

118. Id. art. 67.

119. See, e.g., James Boyle, Shamans, Software and SpleEns: Law ANd the CONSTRUCTION OF THE INFORMATION SOCIETY 138 (1996) (noting that exceptions and limitations are "just as important as the grant of the right itself").

120. TRIPS RESOURCE BOOK, supra note 7, at 126 (emphasis omitted).

121. CORREA, supra note 7, at 99.

122. TRIPS Agreement, supra note 1, art. 7.

123. TRIPS RESOURCE BOOK, supra note 7, at 126.

124. TRIPS Agreement, supra note 1 , art. 7. 
within the larger international trading system. ${ }^{125}$ As the WTO Panel declared in United States-Section 110(5) of the U.S. Copyright Act, "the agreements covered by the WTO form a single, integrated legal system." ${ }^{\text {"126 }}$ Because "[t]he proper balance of rights and obligations is an overriding objective of the WTO system, ${ }^{\prime 127}$ the objectives and principles of the TRIPS Agreement need to be considered in relation to this particular objective. ${ }^{128}$

While it is important to strike a balance within the TRIPS regime, maintaining balance outside the WTO is also very important. As I have noted elsewhere, the spillover effects of intellectual property protection and the increased fragmentation of the international treaty system have necessitated the development of not only endogenous limits to intellectual property protection, but also exogenous limits that can be found in related regimes, such as those concerning public health, human rights, biological diversity, food and agriculture, and information and communications. ${ }^{129}$ As the complexity of the international intellectual property regime continues to increase, the need to better understand the interactions between intellectual property rights and rights in other areas becomes even greater.

\section{B. Article 8.1}

Article 8 provides the interpretative or normative principle of the TRIPS Agreement. ${ }^{130}$ It echoes the Agreement's Preamble

125. Article 3.2 of the Dispute Settlement Understanding, for example, states that the WTO dispute settlement process "serves to preserve the rights and obligations of Members under the covered agreements." Dispute Settlement Understanding, supra note 73, art. 3.2.

126. Panel Report, United States-Section 110(5) of the U.S. Copyright Act, II 6.185, WT/DS160/R (June 15, 2000).

127. CORREA, supra note 7 , at 92 .

128. See TRIPS RESOURCE BOOK, supra note 7, at 130 ("The objectives and principles of TRIPS must be considered in relation to the objectives of the WTO Agreement, which is reflected in its preamble."); Henning Grosse Ruse-Khan, Proportionality and Balancing Within the Objectives for Intellectual Property Protection, in INTELLECTUAL PROPERTY AND HUMAN RIGHTS 161, 162 (Paul L.C. Torremans ed., 2008) (analyzing the role of a proportional balancing of interests within intellectual property protection as part of international economic regulation).

129. See Peter K. Yu, The Political Economy of Data Protection, 84 CHI.-KenT L. REV. (forthcoming Dec. 2009), available at http://ssrn.com/abstract=1046781 (underscoring the need to locate both internal and external limits to intellectual property protection).

130. During a meeting of the TRIPS Negotiating Group, the European Communities distinguished between normative principles and substantive standards. As the Secretariat recounted:

Referring to...the Community paper, on principles related to substantive 
by recognizing "the special needs of the least-developed country Members in respect of maximum flexibility in the domestic implementation of laws and regulations in order to enable them to create a sound and viable technological base."131 In addition, the provision, together with Article 7, "confirms the broad and unfettered discretion that Members have to pursue public policy objectives." ${ }^{132}$ As the TRIPS Resource Book noted, the provision "advises that Members were expected to have the discretion to adopt internal measures they consider necessary to protect public health and nutrition, and to promote the public interest in sectors of vital importance to their socio-economic and technological development." ${ }^{133}$

Article 8.1 lays out the public interest principle in the TRIPS Agreement. ${ }^{134}$ The provision states: "Members may, in

\begin{abstract}
standards of intellectual property rights, the representative of the European Communities said that the "principles" were conceived of as differing from "substantive standards" in important respects. First, principles should be expressed in more general terms than would be a typical substantive standard in an international convention dedicated to substantive standards, such as for example the Paris Convention. Secondly, the translation of the proposed principles into national law would not be verbatim or even close to verbatim; rather parties would be required to follow the thrust of these principles in drafting national legislation in the required detail, taking into account the greater precision often contained in international conventions and in the national legal system in question.
\end{abstract}

TRIPS Negotiating Group, Meeting of 5-8 July 1988: Note by the Secretariat, II 27, MTN.GNG/NG11/8 (Aug. 29, 1988).

131. TRIPS Agreement, supra note 1, pmbl. recital 6 (emphasis added).

132. CORREA, supra note 7, at 108; accord CAROLYN DEERE, THE IMPLEMENTATION GAME 64 (2009) (noting that the objectives and principles of the TRIPS Agreement "provide the legal framework for efforts by developing countries to use the flexibilities in the Agreement and to adapt IP protection at the national level to meet social and development goals"); see also TRIPS RESOURCE BOOK, supra note 7, at 546 ("The fact that [Article 8] only states a 'principle' rather than a specific rule mirrors the intention of the treaty-makers not to rule on the matter itself in any detailed form, but to leave Members broad discretion as regards its implementation."); Yusuf, supra note 34, at 13 ("[I]t may be argued that Article 7 provides the main legal bases for Member States to continue to maintain a degree of domestic control and legislative flexibility over intellectual property policies in a post-TRIPS environment.”).

133. TRIPS RESOURCE BOOK, supra note 7, at 126-27. The authors of the volume went even further to argue that, based on Article 8.1, "measures adopted by Members to address public health, nutrition and matters of vital socio-economic importance should be presumed to be consistent with TRIPS, and that any Member seeking to challenge the exercise of discretion should bear the burden of proving inconsistency." Id. at 127. Nevertheless, it remains unclear whether the WTO panels would require the complainant to satisfy the burden of establishing an abuse of discretion once the challenged measures have been shown to be inconsistent with the TRIPS Agreement. It is more likely that the respondent will be able to rely on Article 8 to show that the challenged measure falls within the discretion reserved to the respondent after the measure has been shown to be consistent with the TRIPS Agreement. Ruse-Khan, supra note 85, at 36-38 (suggesting the difficulty in reversing the burden of proof as proposed by the TRIPS Resource Book).

134. See Yusuf, supra note 34, at 13-15 (discussing the public interest principle). 
formulating or amending their laws and regulations, adopt measures necessary to protect public health and nutrition, and to promote the public interest in sectors of vital importance to their socio-economic and technological development, provided that such measures are consistent with the provisions of this Agreement." ${ }^{135}$ As Professor Correa pointed out, these measures include both measures inside and outside the intellectual property regime:

Article 8.1 broadly recognizes Members' rights "in
formulating or amending their laws and
regulations."... [I]t does not only refer to laws and
regulations on IPRs but to measures adopted in other fields,
for instance, those that restrict the manufacture or
commercialization of IPR-protected goods. Issues
concerning the application of Article 8.1 may, hence, arise
in two contexts, one fully within the IPR realm, and
another one outside it, but with implications on the
protection of IPRs.

Although the original proposal in the less-developed countries' B text included additional measures to protect "public morality" and "national security,"137 those two areas were omitted in the final version of Article 8. These measures, nonetheless, are covered elsewhere in the TRIPS Agreement. Article 27.2 of the TRIPS Agreement allows member states to exclude certain inventions from patentability provided that the prevention of the commercial exploitation of those inventions "is necessary to protect ordre public or morality, including to protect human, animal or plant life or health or to avoid serious prejudice to the environment." ${ }^{138}$ Article 73 further enables member states to pursue their essential security interests and to fulfill obligations under the United Nations Charter in relation to the maintenance of international peace and security. ${ }^{139}$

Article 8.1 is important to less-developed countries because it provides justifications for special exceptions that promote the public interest in sectors of vital importance to socioeconomic and

135. TRIPS Agreement, supra note 1, art. 8.1.

136. CORREA, supra note 7, at 104.

137. As the original proposal in the $B$ text stated:

In formulating or amending their national laws and regulations on IPRs, Parties have the right to adopt appropriate measures to protect public morality, national security, public health and nutrition, or to promote public interest in sectors of vital importance to their socio-economic and technological development.

Communication from Less-Developed Countries, supra note 30, at 7.

138. TRIPS Agreement, supra note 1, art. 27.2 (emphasis added).

139. Id. art. 73. 
technological development. Notably, the provision uses the term "public interest," which can be easily contrasted with the narrower term "ordre public" in Article 27.2 of the TRIPS Agreement. ${ }^{140}$ Because the Appellate Body reminds us that the interpretation of a provision should "take adequate account of the words actually used," ${ }^{141}$ this distinction is likely to be significant.

Moreover, as Professor Correa pointed out, the term "public interest" is likely to be more subjective than the term "ordre public." ${ }^{142}$ According to Gillian Davies, whose book Professor Correa cited for elaboration:

Whether a particular act is "in the public interest"... is probably not subject to any objective tests. Inherent in the noble motive of the public good is the notion that, in certain circumstances, the needs of the majority override those of the individual, and that the citizen should relinquish any thoughts of self-interest in favor of the common good of society as a whole. ${ }^{143}$

Also of interest in Article 8.1 are the ambiguities over what constitutes the necessary measures for "promot[ing] the public interest in sectors of vital importance to their socio-economic and technological development."144 The TRIPS Agreement does not offer any definition of the relevant sectors. In fact, "[s]ectors of vital importance may vary from country to country and region to region, and the provision is not limited to implementation by developing countries." 145

For instance, these sectors can be defined based on their specialization-for example, the pharmaceutical industry versus the automotive industry. The only major constraint seems to be Article 27.1 of the TRIPS Agreement, which prohibits discrimination based on "the place of invention, the field of technology and whether products are imported or locally produced." ${ }^{146}$ The sectors can also be defined based on the size of

140. Id. art. 27.2; see also CORREA, supra note 7, at 105 ("Public interest' is a concept broader than 'ordre public' used in Article 27.2 of the TRIPS Agreement." (footnote omitted)).

141. Appellate Body Report, United States-Standards for Reformulated and Conventional Gasoline, pt. III.B, WT/DS2/AB/R (Apr. 29, 1996); see TRIPS RESOURCE BoOK, supra note 7, at 118 ("A general principle of treaty interpretation is that terms are presumed not to be surplus. Words are in a treaty for a reason and should be given their ordinary meaning in its context.").

142. CORREA, supra note 7, at 105.

143. GILlian Davies, Copyright AND THE PUBLIC INTEREST 4 (2002), quoted in CORREA, supra note 7, at 105-06.

144. TRIPS Agreement, supra note 1, art. 8.1.

145. TRIPS RESOURCE BOOK, supra note 7, at 127.

146. TRIPS Agreement, supra note 1, art. 27.1. 
the sectors or their stage of development-for example, infant industry or small and mid-sized enterprises. In those scenarios, Article 27.1 will not even present a barrier, except in situations when there is de facto discrimination based on the composition of the affected industries.

In his new treatise on the TRIPS Agreement, Professor Correa went even further to argue that each member state should be able to decide what constitutes these sectors based on their needs, goals, and interests. ${ }^{147}$ As he explained:

On the one hand, "sectors" may refer to economic activities at different levels of aggregation ([e.g.,] agriculture, maize production), as well as to certain groups of economic agents ([e.g.,] small and medium enterprises). Although the adjective "vital importance" would seem to limit the scope of the provision to specially significant sectors, which sector is important or not is also subject to determination by the concerned Member in the light of its "socio-economic and technological development."

... [T] he concept of "socio-economic and technological development" is broad enough to encompass any sector, socially, economically, or technologically relevant. Thus, the importance of a sector may be measured by its contribution to GNP; but it may be also socially important, despite a low contribution thereto. ${ }^{148}$

According to Professor Correa, permissible actions may include "measures excluding foreign direct investment in certain sectors, and the regulation of royalty rates and other conditions in licensing agreements." As As he reminded us, "[t]hese regulations were applied by many developing (and some developed) countries during the $1970 \mathrm{~s}$ and $1980 \mathrm{~s}$ but were gradually abandoned in the context of more liberal policies towards foreign direct investment."

With the rapid development experienced by complex economies such as Brazil, China, India, and South Africa, what constitutes sectors of vital importance may take on new

147. See CORREA, supra note 7, at 106 (noting that identifying these sectors should be considered "a matter for the particular Members to decide"); see also Andrés Moncayo von Hase, The Application and Interpretation of the Agreement on Trade-Related Aspects of Intellectual Property Rights, in INTELlECTUAL PROPERTY AND INTERNATIONAL TRADE, supra note 34 , at 83,120 (" $[\mathrm{T}]$ he discretion of members to establish a balance of rights and obligations between technology producers and users within their boundaries should not be replaced by the judgments or interpretative constructions of the [Dispute Settlement Body].").

148. CORREA, supra note 7 , at 106.

149. Id. at 105.

150. Id. (footnote omitted). 
complexities. Unlike the United States and most members of the European Communities, these economies have the distinctive characteristics of having wide internal divergences in their socioeconomic conditions and technological capabilities. ${ }^{151}$ It is therefore difficult to determine what constitutes the relevant sectors in those countries. As I have suggested in the past, China may prefer stronger protection of intellectual property rights in entertainment, software, semiconductors, and selected areas of biotechnology, even though it may remain reluctant to increase protection for pharmaceuticals, chemicals, fertilizers, seeds, and foodstuffs, due to its huge population, continued economic dependence on agriculture, and concerns about public health and its people's overall wellbeing. ${ }^{152}$

Although Article 8.1 can be interpreted broadly to promote the development goals of less-developed countries, the provision contains two major constraints, both of which were added at the request of developed countries in the last stages of the negotiation. ${ }^{153}$ The first constraint concerns the necessity requirement, which is somewhat similar to the one found in Article XX of the GATT. ${ }^{154}$ By limiting the flexibilities available in the TRIPS Agreement, this requirement threatens to impede the public policy goals of many less-developed countries.

For example, without taking into account the language in Paragraph 4 of the Doha Declaration, ${ }^{155}$ Article 8 of the TRIPS Agreement does not allow member states to adopt any measures they deem useful to protect public health and nutrition. Rather, the provision states explicitly that they can only adopt measures that are necessary for those purposes. In fact, they may not even adopt measures that they consider necessary for those purposes. As Wesley Cann explained,

the use of the term "necessary," as opposed to the language "it considers necessary" employed in the Article 73 security exception, would seem to indicate that the imposition of these measures are not within the absolute discretion of the

151. See Peter K. Yu, International Enclosure, the Regime Complex, and Intellectual Property Schizophrenia, 2007 MICH. ST. L. REV. 1, 23-27 (examining the regional and sectoral disparities in intellectual property protection and enforcement within China).

152. See id. at 25-26.

153. See GERVAIS, supra note 2, at 121; Yusuf, supra note 34 , at 14

154. See CORREA, supra note 7, at 106. For the WTO document on the necessity requirement, see Working Party on Domestic Regulation, "Necessity Tests" in the WTO: Note by the Secretariat, S/WPDR/W/27 (Dec. 2, 2003).

155. Doha Declaration, supra note 61, II 4 (stipulating that member states "agree that the TRIPS Agreement does not and should not prevent Members from taking measures to protect public health"). 
invoking Member, but are instead subject to potential WTO review in regard to their validity. ${ }^{156}$

Even worse, the provision requires the measures to be "consistent with the provisions of [the TRIPS] Agreement." This second constraint greatly erodes the pro-development aspect of Article 8. As Professor Gervais noted:

It is ... tempting to conclude that this Article may serve as a basis for broader exceptions than [Article 7]. That is not the case, however. Both [Paragraphs of Article 8] are limited by the use of the phrase "consistent with the provisions of this Agreement".... Given the phrase added by negotiators, it would be difficult to justify an exception not foreseen under the Agreement, unless it is an exception to a right not protected under other provisions of the TRIPS Agreement or those of other international instruments incorporated in TRIPS. ${ }^{157}$

Fortunately for less-developed countries, whether one fails the TRIPS-consistency requirement will depend on the overall interpretation of the TRIPS Agreement. When Articles 7 and 8 are read together, a careful and effective interpretation of Article 7 may help remove the potential inconsistency with the TRIPS Agreement. Also of great importance is a skillful use of the Preamble, which arguably can be viewed as a "condensed expression of [the] underlying principles" of the TRIPS Agreement. ${ }^{158}$ As Professor Correa pointed out, consistency with the TRIPS Agreement "should be assessed in the light of Article 7 and of the Preamble, that is, taking the balance of rights and obligations and the social and economic welfare into account."159 Abdulqawi Yusuf went even further: "[E]ven though certain public interest measures may be inconsistent with some of the specific standards laid down in the TRIPS Agreement, it is their overall consistency with the agreement that should be taken into account."160

The developed countries' push for the addition of these requirements is understandable. From their standpoint, both requirements are greatly needed to ensure that the protections offered by the TRIPS Agreement will not be undercut by

156. Wesley A. Cann, Jr., On the Relationship Between Intellectual Property Rights and the Need of Less-Developed Countries for Access to Pharmaceuticals: Creating a Legal Duty to Supply Under a Theory of Progressive Global Constitutionalism, 25 U. PA. J. INT'L ECON. L. 755, 808 (2004).

157. GERVAIS, supra note 2, at 121-22.

158. Id. at 80 ("The preamble, together with footnotes, should be considered as an integral part of the agreement, a condensed expression of its underlying principles.").

159. CORREA, supra note 7, at 104.

160. Yusuf, supra note 34 , at 14 . 
measures adopted under the pretexts of protecting health and nutrition or promoting socioeconomic and technological development. ${ }^{161}$ Unfortunately for the less-developed world, the added requirements in Article 8.1 have created the perverse effect of privileging intellectual property protection over other, arguably more important, socioeconomic goals, such as providing access to essential medicines to combat HIV/AIDS, tuberculosis, malaria, and other epidemics. Such an effect is undoubtedly one of the Agreement's more harmful unintended consequences. To some extent, the added requirements and the less-developed countries' willingness to accept the modifications during the TRIPS negotiations reflect the countries' then-limited understanding of the dramatic adverse spillover effects of strong international intellectual property protection. ${ }^{162}$ Nevertheless, even if these countries were aware of these effects, they would have been unlikely to "withstand the considerable political resources that the developed countries' negotiators brought to bear to secure the TRIPs agreement." 163

It is also problematic that the safeguards available in the TRIPS Agreement are more restrictive than those available under Article XX of the GATT. As noted in the TRIPS Resource Book:

TRIPS does not contain a general safeguard measure comparable to Article XX of the GATT 1994 or Article XIV of the GATS. For those other Multilateral Trade Agreements (MTAs), the necessity to protect human life or health may take priority over the generally applicable rules of the agreement, subject only to general principles of nondiscrimination. Yet when it comes to intellectual property, the "exceptions" are circumscribed with various procedural or compensatory encumbrances, making their use more difficult. ${ }^{164}$

161. See Hanns Ullrich, Expansionist Intellectual Property Protection and Reductionist Competition Rules: A TRIPS Perspective, 7 J. INT'L ECON. L. 401,410 (2004). Specifically, Professor Ullrich stated:

[The TRIPS-consistency requirement] must be read as a caveat against an excessive exercise of competition policy, which the TRIPS Agreement, by its purpose and express wording, otherwise leaves Members free to define. It means that they may not use antitrust regulation as a pretext to undermine the protection of IPRs as guaranteed by the TRIPS Agreement.

Id.; see also TRIPS RESOURCE BOOK, supra note 7, at 133 ("Proponents of high levels of IPR protection argue this is necessary to protect against abuse of exceptions, and that IPRs such as patents represent a special case.").

162. See Yu, supra note 11, at 419 .

163. Christopher MaY, THE WORLd INTELlectual Property ORganization: RESURGENCE AND THE DEVELOPMENT AGENDA 30 (2007).

164. TRIPS RESOURCE BOOK, supra note 7, at 132; accord Cann, supra note 156, at 808-09 ("II]t can be argued that the phrase "provided that such measures are consistent 
It is therefore no surprise that concern over the restrictiveness of these safeguards in the public health area in part precipitated the Doha negotiations, ${ }^{165}$ which sought to renegotiate the ways safeguards are handled in the TRIPS Agreement. Viewed against this background, the Ministerial Declaration and the Doha Declaration may have given Article 8 a "higher legal status not only for the negotiations but in interpreting the Agreement in the context of, e.g., disputesettlement procedures." ${ }^{166}$ It is indeed significant that they omitted the necessity requirement. Such omission is likely to create interesting discussion concerning the interpretation and implementation of the TRIPS Agreement.

\section{Article 8.2}

Article 8.2 provides: "Appropriate measures, provided that they are consistent with the provisions of this Agreement, may be needed to prevent the abuse of intellectual property rights by right holders or the resort to practices which unreasonably restrain trade or adversely affect the international transfer of technology."167 The structure of this provision is similar to that of Article 8.1, and the provision resembles its predecessor in including the TRIPS-consistency requirement.

with the provisions of the Agreement' is substantially more restrictive than the General Exceptions found in Article XX of the [GATT], which allows measures that would otherwise be inconsistent with the GATT Agreement."). Although commentators have explored whether the general exceptions in Article XX of the GATT are permitted under the TRIPS Agreement, many have expressed skepticism over such application. E.g., GERVAIS, supra note 2, at 122 ("The Appellate Body [in United States-Section 211 Omnibus Appropriations Act of 1998] seemed to conclude that no new exception based on the GATT would be allowed if it violated a substantive TRIPS obligation."). The WTO Panel's decision in European Communities-Protection of Trademarks and Geographical Indications for Agricultural Products and Foodstuffs also seems to have confirmed this skeptical position. Panel Report, European Communities-Protection of Trademarks and Geographical Indications for Agricultural Products and Foodstuffs, WT/DS174/K (Mar. 15, 2005). As the panel declared:

[T] here is no hierarchy between the TRIPS Agreement and GATT 1994, which appear in separate annexes to the WTO Agreement. The ordinary meaning of the texts of the TRIPS Agreement and GATT 1994, as well as Article II:2 of the WTO Agreement, taken together, indicates that obligations under the TRIPS Agreement and GATT 1994 can co-exist and that one does not override the other.

Id. II 7.208 .

165. See CORREA, supra note 7, at 108 ("The extent to which the final proviso of Article 8.1 ('provided that such measures are consistent with the provisions of this Agreement') would mean that IPRs could override public health measures, was a major reason why developing countries proposed the adoption of [the Dleclaration.").

166. GERVAIS, supra note 2, at 120.

167. TRIPS Agreement, supra note 1, art. 8.2. 
To some extent, Article 8.2 is somewhat redundant. Virtually all the public policy objectives mentioned in the provision have already been addressed elsewhere in the Agreement. For example, Article 30 allows member states to "provide limited exceptions to the exclusive rights conferred by a patent" on the condition that such exceptions satisfy the threestep test-that is, they are "[1] limited[,] ... [2] do not unreasonably conflict with a normal exploitation of the patent and [3] do not unreasonably prejudice the legitimate interests of the patent owner, taking account of the legitimate interests of third parties." ${ }^{\prime 168}$ Article 31(k) enumerates special conditions for members to issue compulsory licenses in an effort "to remedy a practice determined after judicial or administrative process to be anti-competitive." ${ }^{\text {"169 }}$ That provision also allows for "[t]he need to correct anti-competitive practices [to] be taken into account in determining the amount of remuneration in such cases." ${ }^{.170}$ In addition, Article 40 permits member states to take appropriate measures to curb "an abuse of intellectual property rights having an adverse effect on competition in the relevant market."

While the provision no doubt offers added support to these provisions, it is likely to have limited legal effect. Article 8, for example, is unlikely to provide the legal basis for "justify[ing] an exception not foreseen under the Agreement, unless it is an exception to a right not protected under other provisions of the TRIPS Agreement or those of other international instruments incorporated in TRIPS." ${ }^{\text {172 }}$ It is therefore no surprise that Professor Gervais has described Article 8 as "essentially a policy statement that explains the rationale for measures taken under [Articles] 30, 31 and 40."173

Nevertheless, Article 8.2 is important for both historical reasons and symbolic effect. The provision serves as a conspicuous reminder of what less-developed countries initially considered within the mandate of the GATT negotiations. ${ }^{174}$ As

168. Id. art. 30 .

169. Id. art. $31(\mathrm{k})$.

170. Id.

171. Id. art. 40.

172. GervaIS, supra note 2, at 121-22.

173. Id. at 121. But see TRIPS RESOURCE BOOK, supra note 7, at 546 (disagreeing with Professor Gervais and observing that 'Article 8.2 states a 'principle', which is different from a mere 'policy statement").

174. See TRIPS RESOURCE BOOK, supra note 7, at 127 ("This Article to a large extent reflects the view advanced by the Indian delegation, among others, during the Uruguay Round negotiations that a main objective of TRIPS should be to provide mechanisms to restrain competitive abuses brought about by reliance on IPR protection."). 
India noted in a detailed intervention during a meeting of the TRIPS Negotiating Group, "it was only the restrictive and anticompetitive practices of the owners of the IPRs that could be considered to be trade-related because they alone distorted or impeded international trade." ${ }^{175}$ Notably, India "did not regard the other aspects of IPRs [discussed in the Group at that time] to be trade-related," that is, not within the mandate set up by the Punta del Este Declaration. ${ }^{176}$

Similar structure was followed in the B text, which was divided into two parts. As Adronico Adede noted, "By presenting the proposed text of a TRIPS agreement into two parts, the developing countries wanted ... to signal their determination to emphasize the part dealing with trade in counterfeit goods while minimizing the part relating to substantive standards on IPRs." ${ }^{177}$ Notably, Articles 7 and 8 were taken from the first part of the B text, which focused on what less-developed countries considered trade-related intellectual property matters. ${ }^{178}$

\section{Multiple Uses OF ARTiCles 7 AND 8}

Articles 7 and 8, which outline the objectives and principles of the TRIPS Agreement, constitute "a central piece for the implementation and interpretation of the TRIPS Agreement."179 These objectives and principles become even more important due to the revolutionary nature of the TRIPS Agreement, which has transformed the international intellectual property system from an inter-national patchwork system to a global supranational code. ${ }^{180}$ As elaborated in the TRIPS Resource Book:

\section{Id. at 121 .}

176. Id.

177. Adede, supra note 30 , at 28.

178. See Communication from Less-Developed Countries, supra note 30, art. 2 .

179. CORREA, supra note 7, at 108.

180. See Yu, supra note 11, at 354-75; see also Paul Edward Geller, From Patchwork to Network: Strategies for International Intellectual Property in Flux, 9 DUKE J. CoMP. \& INT'L L. 69, 70-71 (1998) (describing how the network model has now replaced the patchwork model under which international intellectual property norms were structured in the past century); Jane C. Ginsburg, International Copyright: From a "Bundle" of National Copyright Laws to a Supranational Code?, 47 J. CopYRIGHT SOC'Y U.S.A. 265, 289 (2000). Professor Ginsburg stated:

'International copyright' can no longer accurately be described as a 'bundle' consisting of many separate sticks, each representing a distinct national law, tied together by a thin ribbon of Berne Convention supranational norms. Today's international copyright more closely resembles a giant squid, whose many national law tentacles emanate from but depend on a large common body of international norms. 
Since TRIPS brought the regulation of intellectual property rights into the GATT, and now WTO, multilateral trading system for the first time, there is no pre-TRIPS situation in respect to the objectives and principles of the Agreement. In other words, the objectives and principles of ... TRIPS are unique to the Agreement.

... Neither the Paris nor Berne Convention included provisions analogous to Articles 7 and 8 . That is, there are no provisions that act to establish an overarching set of principles regarding the interpretation and implementation of the agreement. ${ }^{181}$

Because the pre-TRIPS international intellectual property conventions do not contain "provisions that act to establish an overarching set of principles regarding the interpretation and implementation of the agreement," one could argue that "the elaboration of objectives and principles in Articles 7 and 8 may well be viewed as a means to establish a balancing of interests at the multilateral level to substitute for the balancing traditionally undertaken at the national level." 182 To some extent, the two provisions codify the multilateral norms concerning the protection of the public interest in intellectual property law. ${ }^{183}$ As such, they "qualify the scope of harmonization [of intellectual property standards] at the national level."184

This Part discusses the role Articles 7 and 8 can play in facilitating a more flexible interpretation and implementation of the TRIPS Agreement. It focuses, in particular, on five ways in which the provisions can be put into effective use: (1) as a guiding light for the interpretation and implementation of the Agreement; (2) as a shield against aggressive expansion of intellectual property rights and demands for "TRIPS-plus" protections; (3) as a sword to challenge the lack of balance in the international intellectual property system; (4) as a bridge to connect the TRIPS regime with intellectual property and other

181. TRIPS RESOURCE BOOK, supra note 7, at 119 (footnote omitted).

182. Id.; accord Yusuf, supra note 34, at 10 ("[T] highlight the importance of the public policy objectives underlying national IPR systems, the necessity of recognizing those objectives at the international level and the need to specify some basic principles which could subsequently elucidate the application of any standards established in the TRIPS Agreement.").

183. See Yusuf, supra note 34, at 12 ("[Article 7] embodies an international recognition of the primary public-policy objectives for which governments grant protection and enforcement to IPRs, namely the promotion of technological innovation and the transfer and dissemination of technology.").

184. Id. at 14. 
related international regimes; and (5) as a seed for the development of new international intellectual property norms.

\section{A. Guiding Light}

Among the five different uses, the use of the provisions to clarify the TRIPS Agreement is the most obvious. Such a use is strongly supported by the WTO documents. Article 3.2 of the Dispute Settlement Understanding states that provisions of the covered agreements are to be clarified "in accordance with customary rules of interpretation of public international law, ${ }^{185}$ including those stipulated in the Vienna Convention. Since United States-Standards for Reformulated and Conventional Gasoline ${ }^{186}$ the first case decided by a WTO panel, the WTO panels and the Appellate Body have both embraced Article 31 of the Vienna Convention as a general rule of interpretation. As the Panel declared in its report:

In resolving this interpretative issue the Panel referred, in conformity with Article 3.2 of the Understanding on Rules and Procedures Governing the Settlement of Disputes, to the Vienna Convention on the Law of Treaties, which states in Article 31 that "a treaty shall be interpreted in good faith in accordance with the ordinary meaning to be given to the terms of the treaty in their context and in the light of its object and purpose". ${ }^{187}$

The Panel's position was subsequently endorsed by the Appellate Body, which described Article 31 of the Vienna Convention as "a fundamental rule of treaty interpretation." 188 In the TRIPS context, this rule of interpretation was first applied in India Patent Protection for Pharmaceutical and Agricultural Chemical Products, which concerned India's failure to provide a mailbox system as required by Article 70.8 of the TRIPS Agreement. ${ }^{189}$

Article 31.1 of the Vienna Convention stipulates that "[a] treaty shall be interpreted in good faith in accordance with the ordinary meaning to be given to the terms of the treaty ... in the light of its object and purpose." ${ }^{190}$ Because Articles 7 and 8 were

185. Dispute Settlement Understanding, supra note 73, art. 3.2.

186. Panel Report, United States-Standards for Reformulated and Conventional Gasoline, WT/DS2/R (Jan. 29, 1996).

187. Id. II 6.7.

188. Appellate Body Report, United States-Standards for Reformulated and Conventional Gasoline, pt. III.B, WT/DS2/AB/R (Apr. 29, 1996).

189. Panel Report, India-Patent Protection for Pharmaceutical and Agricultural Chemical Products, pt. VII.A-B, WT/DS50/R (Sept. 5, 1997).

190. Vienna Convention, supra note 72, art. 31.1 (emphasis added). 
the designated provisions for determining the objectives and principles of the TRIPS Agreement, ${ }^{191}$ the Vienna Convention requires that the Agreement be interpreted in the light of these two provisions. As Professor Correa reminded us, "[i]f the Agreement itself contains a definition of its purpose, as Article 7 does, panels and the Appellate Body cannot ignore it or create their own definition in interpreting other provisions of the Agreement."

Although Articles 7 and 8 have been used only sparingly in WTO panel decisions, the panels thus far have referred favorably to the provisions. In Canada-Patent Protection of Pharmaceutical Products, for example, the Panel declared: "Both the goals and the limitations stated in Articles 7 and 8.1 must obviously be borne in mind when lexamining the words of the limiting conditions in Article 30] as well as those of other provisions of the TRIPS Agreement which indicate its object and purposes." 193 This decision was particularly important because it was issued before the adoption of the Doha Declaration. As Professor Abbott pointed out:

In late 1999, the political pressures resulting from aggressive US and EC policies on TRIPS were building up, but public antipathy towards that conduct had not yet manifested itself at the level surrounding the Medicines Act trial in South Africa. The Doha Declaration on the TRIPS Agreement and Public Health was about two years off. ${ }^{194}$

During the Doha negotiations, Articles 7 and 8 were "singled out" for their special importance. ${ }^{195}$ Paragraph 19 of the Ministerial Declaration stated explicitly that the work of the TRIPS Council "shall be guided by the objectives and principles set out in Articles 7 and 8 of the TRIPS Agreement and shall take fully into account the development dimension." ${ }^{\text {"196 }}$ Although the legal effect of this document remains unclear, the document "may lead a panel to take a longer look at how these provisions should be interpreted in the context of the Agreement as a whole, especially with respect to the need for "balance."'197

191. TRIPS Agreement, supra note 1, arts. 7-8.

192. CORREA, supra note 7, at 93.

193. Panel Report, Canada-Patent Protection of Pharmaceutical Products, 97 7.26, WT/DS114/R (Mar. 17, 2000).

194. Frederick M. Abbott, Bob Hudec as Chair of the Canada-Generic Pharmaceuticals Panel-The WTO Gets Something Right, 6 J. INT'L ECON. L. 733, 736 (2003).

195. GeRVAIS, supra note 2, at 120.

196. Ministerial Declaration, supra note 60, II 19.

197. GERVAIS, supra note 2 , at 120. 
Articles 7 and 8 become even more important in light of the many ambiguities built into the TRIPS Agreement. ${ }^{198}$ Because Articles 7 and 8 memorialize the hard-fought bargains lessdeveloped countries have won through the TRIPS negotiations, these provisions provide policymakers, WTO panels, and the Appellate Body with objective clues as to how ambiguous words in the TRIPS Agreement are to be interpreted. "The context provided by Articles 7 and 8 may [also] be of particular importance to correctly interpret the extent of several obligations and exceptions under the TRIPS Agreement, such as the concepts of 'third party' and 'legitimate interests' in Article 30, 'unfair commercial use' under Article 39.3, and 'abuse' in Articles 40 and 50.3, among others." 199

Consider, for example, the word "review" in Article 27.3(b) of the TRIPS Agreement, which concerns the patentability of diagnostic, therapeutic, and surgical methods and plants and animals other than micro-organisms. ${ }^{200}$ As Professor Correa pointed out, "there has been no agreement in the Council for TRIPS on the meaning of 'review."'201 While developed countries interpreted the word to mean "review of implementation," lessdeveloped countries interpreted the word to suggest the possibility for "revising" the Agreement to meet their needs and interests. ${ }^{202}$

Likewise, Sisule Musungu reminded us of the different ways to conceptualize the transitional periods built into the TRIPS Agreement and extended through the Doha Declaration:

While giving extra time due to administrative and financial constraints was one aim, the central objective of the LDCs [least-developed countries] transition period under the TRIPS Agreement is different. Article 66.1 of TRIPS read together with the Preamble of the TRIPS Agreement and its

198. As Professor Correa observed with respect to the Preamble of the TRIPS Agreement:

The text of the preamble is an important source of interpretation to clarify the meaning of treaty provisions. In fact, owing to the controversial nature of the issues covered by the TRIPS Agreement, many of its provisions are ambiguous or deliberately leave Members room for interpretation. The "context" provided by the preamble becomes, hence, particularly relevant in this case.

CORREA, supra note 7, at 17. If the Preamble is that important, one can imagine how much more important the text of Articles 7 and 8 would be in light of the wide array of ambiguities built into the Agreement.

199. Id. at 94-95.

200. TRIPS Agreement, supra note 1, art. 27.3(b).

201. Carlos M. Correa, intellectual Property Rights, the WTO and DEVELOPING COUNTRIES 211 (2000).

202. Id. 
objectives under Article [7] envisage the purpose and objectives of the LDCs transition period to be to respond and address: the special needs and requirements of these countries; and the need for maximum flexibility to help these countries create a sound and viable technological base. ${ }^{203}$

Indeed, Jayashree Watal described these ambiguous words and phrases as "constructive ambiguit[ies]."204 These ambiguities are constructive because they can be strategically interpreted and deployed to provide less-developed countries with additional "wiggle room" to implement their obligations under the TRIPS Agreement. ${ }^{205}$ These constructive ambiguities therefore provide less-developed countries with a bulwark against the continuous expansion of intellectual property rights. ${ }^{206}$ If strategically used, they will allow less-developed countries to actively push for interpretations that meet their needs, interests, and goals. They will also preserve the much-needed policy space that has been appropriately reserved to them during the TRIPS negotiations. In Watal's view, a constructive resolution of these ambiguities may even provide less-developed countries a "means of 'clawing' back much of what was lost in the negotiating battles in TRIPS." ${ }^{207}$

Politically, Articles 7 and 8 are also important because they legitimize the TRIPS Agreement. They confirm that the Agreement was a bargain struck between developed and lessdeveloped countries over a multiyear negotiation process. Because the two provisions were directly taken from the lessdeveloped countries' B text with limited modification and those provisions are the very few provisions taken from this text, ${ }^{208}$ the taken language should be considered highly important. If such language is ignored, it would be very hard to make a good faith argument that the TRIPS Agreement was a legitimate bargain between developed and less-developed countries. As Abdulqawi Yusuf reminded us:

203. Sisule Musungu, A Conceptual Framework for Priority Identification and Delivery of IP Technical Assistance for LDCs During the Extended Transition Period Under the TRIPS Agreement 5 (Quaker United Nations Office, Issue Paper No. 7, 2007), available at http://www.quno.org/geneva/pdf/economic/Issues/Priority-ID-English.pdf (endnote and emphasis omitted).

204. WATAL, supra note 2 , at 7 .

205. J.H. Reichman, From Free Riders to Fair Followers: Global Competition Under the TRIPS Agreement, 29 N.Y.U. J. INT'L L. \& POL. 11, 28 (1997).

206. See WATAL, supra note 2 , at 7-8.

207. Id. at 7 .

208. See Gervais, supra note 45 , at 30 ("The only true measures they obtained (in addition to articles 7 and 8) were transitional periods to implement the Agreement."). 
To the extent that the operative provisions of the TRIPS text principally reflected the positions of the developed countries and established higher standards of protection for IPRs, it would appear that the developing countries found comfort and consolation in the clear statement of the objectives they proposed in the preambular clauses as well as in Article 7, together with the recognition of some of the principles they suggested in Article $8 .^{209}$

There is a tendency for policymakers in developed countries and the global intellectual property industries to demand concessions in exchange for proposals that further the development dimension of the TRIPS Agreement. However, these demandeurs tend to overlook the fact that the TRIPS Agreement is now in a deepening crisis. Its legitimacy has been called into question by the high standards of protection and enforcement that ignore the needs, interests, and goals of the less-developed member states. ${ }^{210}$ If the Agreement is to regain its legitimacy, the less-developed countries' side of the bargain, including the objectives and principles set forth in Articles 7 and 8, ought to be kept.

Finally, Articles 7 and 8 are important because WTO panels and the Appellate Body are often "tempted to introduce their own policy views on IPRs." ${ }^{211}$ For example, in determining the normal exploitation of intellectual property rights, the panels have taken views that focus narrowly on the right holders' economic interests. As Professor Correa lamented in relation to CanadaPatent Protection of Pharmaceutical Products:

The panels' view, while emphasizing stimulation to innovation, fails to consider other equally essential objectives of the patent grants. Like other IPRs, patents are granted in the public interest, and not merely to allow the patent owners to obtain the "economic returns anticipated from a patent's grant of market exclusivity." The diffusion of knowledge and its continuous improvement are equally important objectives of that system.

If the commercial interests of the patent owner were the only ones to be considered, the interpretation of the Agreement would in practice defeat its intended objectives. ${ }^{212}$

Likewise, Ruth Okediji expressed her disappointment over the decisions of the WTO panels and the Appellate Body:

209. Yusuf, supra note 34, at 12.

210. See SELL, supra note 38 , at 173 ("The shaky foundations of [the TRIPS] regime raise important concerns about accountability and legitimacy.").

211. CORREA, supra note 7 , at 94.

212. Id. 
A particularly revealing aspect of these disputes is the way each of the Panels and the Appellate Body have ducked the thorny question of how to apply the preambular statements and the broad themes of Article 7 and 8 to evaluate the substantive obligations of the TRIPS Agreement. While tribunals can use strict construction to constrict or expand the requirements of TRIPS, the vagueness of these general qualifications in Articles 7 and 8 will likely lead to a oneway ratchet of rights. In each of these cases, the dispute panels have invariably emphasized the market preserve of intellectual property owners as a dominant factor in determining whether a TRIPS violation had occurred. Further, the cases suggest that the panels, in focusing on the purpose and objective of the TRIPS agreement, and the context of the negotiations, have interpreted the provisions almost solely in light of the economic expectations of the private right holders. ${ }^{213}$

As Graeme Dinwoodie reminded us, "the incorporation of intellectual property agreements within trade mechanisms might (if trade concerns become paramount) deprive intellectual property policymaking of the rich palette of human values that historically has influenced its formulation." ${ }^{214}$

In sum, Articles 7 and 8 provide important tools to ensure that the WTO panels focus on the compromise struck between developed and less-developed countries during the TRIPS negotiations. ${ }^{215}$ Even if the panels were to ignore such a bargain, the two provisions provide the needed textual evidence for the Appellate Body to correct such misinterpretations.

\section{B. Shield}

Related to the first use, and partly as its outcome, is the second-the use of Articles 7 and 8 as a shield to defend a member state's use of flexibilities that have been built into the TRIPS Agreement. The use of these provisions for defensive purposes is particularly important in light of the fact that developed countries have been the predominant users of the WTO dispute settlement process. ${ }^{216}$ Such use is even more important, considering the fact that WTO panel decisions may ultimately affect the tone and direction of future negotiations

213. Okediji, supra note 54, at 914-15 (footnote omitted).

214. Graeme B. Dinwoodie, The Architecture of the International Intellectual Property System, 77 CHI.-KENT L. REV. 993, 1004 (2002).

215. See Yu, supra note 2, at 371-73 (discussing the bargain narrative of the TRIPS Agreement).

216. See Davey, supra note 55, at 17. 
between developed and less-developed countries-whether the negotiations are at the bilateral, regional, or multilateral levels. As Gregory Shaffer explained in the WTO context:

[P]articipation in WTO political and judicial processes are complementary. The shadow of WTO judicial processes shape bilateral negotiations, just as political processes and contexts inform judicial decisions. If developing countries can clarify their public goods priorities and coordinate their strategies, then they will more effectively advance their interests in bargaining conducted in WTO law's shadow, and in WTO legal complaints heard in the shadow of bargaining. They, in turn, will be better prepared to exploit the "flexibilities" of the TRIPS Agreement, tailoring their intellectual property laws accordingly, and will gain confidence in their ability to ward off US and EC threats against their policy choices. ${ }^{217}$

The previous Section discussed the use of Articles 7 and 8 to clarify the ambiguous provisions of the TRIPS Agreement. While it is important to seek clarifications in a member state's efforts to implement the Agreement, there are situations in which the provisions are open to many different interpretations. As Professor Frankel pointed out:

Using [Articles 7 and 8] to help interpret the object and purpose is only a starting point. There are inherent difficulties in that the articles seek to capture competing objectives and purposes, and they represent a compromise between the disparate views of those entering the agreement. What amounts to "promotion of technological innovation and to the transfer and dissemination of technology" is, by its nature, open to some debate and the viewpoint of any WTO member is likely to relate to its economic position. ${ }^{218}$

As a result, it is important for less-developed countries to interpret the provisions in a way that would highlight the social aspect, development dimension, and public policy goals of the TRIPS Agreement. ${ }^{219}$

217. Gregory Shaffer, Recognizing Public Goods in WTO Dispute Settlement: Who Participates? Who Decides? The Case of TRIPS and Pharmaceutical Patent Protection, $7 \mathrm{~J}$. INT'L ECON. L. 459, 476-77 (2004) (footnote omitted).

218. Frankel, supra note 72, at 393.

219. As Professor Frankel continues:

Treaty interpretation is both a powerful and a limited tool. It is powerful because an interpretation method can be used to reach a result that favors one disputant over another. It is limited because it is only a tool of interpretation and as such is merely a road map to an existing network of obligations. Interpretation cannot be used to create new obligations or to resolve a true 
Unfortunately, such interpretation has been made difficult by a lack of institutional capacity and a growing orientation toward treaty compliance, not to mention a misplaced and misleadingly simplistic hope that greater compliance with the treaty will result in an increase in foreign direct investment, technology transfer, inward trade flows, and human capital. ${ }^{220}$ To help restore the balance of the international intellectual property system, the TRIPS Agreement therefore needs to be interpreted through a prodevelopment lens, ${ }^{221}$ with an emphasis on the objectives and principles set forth in Articles 7 and 8 of the TRIPS Agreement and the flexibilities expressly recognized in those provisions.

If such interpretations are to be developed, a better understanding of the development implications of the TRIPS Agreement is in order. It is also essential to develop model laws, policies, and best practices that are "development friendly" and that take account of the needs, interests, and goals of lessdeveloped countries. Because these models can serve as good starting points for international negotiations, they are particularly useful as a response to the growing use of "TRIPSplus" bilateral and regional trade agreements. ${ }^{222}$ The models can also help less-developed countries build the much-needed experience and human capital to tailor their laws and policies to their specific local conditions. ${ }^{223}$

Articles 7 and 8 can be used to help develop these models in three ways. First, as Jerome Reichman pointed out in the context of promoting access to essential medicines, the safeguards implicit in Articles 7 and 8 can be used to "convince the Council

conflict of treaty norms by choosing one norm over another. Interpretation can only be used to establish whether the treaty itself prefers one norm over another; in other words, whether the parties have in fact agreed that one norm prevails over another and have demonstrated this intention in the words of the treaty.

Id. at 368 .

220. See DEERE, supra note 132 , at 242 ("TRIPS implementation in the OAPI [African Intellectual Property Organization] countries was shaped by a pro-IP and 'compliance-plus'-oriented political environment."); Keith E. Maskus \& Jerome H. Reichman, The Globalization of Private Knowledge Goods and the Privatization of Global Public Goods, in INTERNATIONAL PUBlic GoOds AND TRANSFER OF TECHNOLOGY UNDER A Globalized Intellectual Property Regime 3, 18 (Keith E. Maskus \& Jerome $\mathrm{H}$. Reichman eds., 2005) (expressing concern that many less-developed countries are "compliance oriented").

221. See Yu, supra note 2, at 387-89.

222. See Yu, supra note 11, at 392-400 (discussing the growing use of bilateral and regional trade agreements).

223. See Rochelle Cooper Dreyfuss, TRIPS-Round II: Should Users Strike Back?, 71 U. CHI. L. REV. 21, 25 (2004) (noting that many less-developed countries lack "experience with intellectual property protection [and] sufficient human capital (in the form of legal talent) to codify wiggles into law"). 
for TRIPS ... to recommend narrowly described waivers to meet specified circumstances for a limited period of time."224 In the alternative, less-developed countries can use those provisions in the WTO dispute settlement process to provide defense for their needed public health measures. As Professor Reichman explained:

[D]eveloping country defendants responding to complaints of nullification and impairment under Article $64 \mathrm{might}$ invoke the application of Articles 7 and 8(1) to meet unforeseen conditions of hardship. This defense, if properly grounded and supported by factual evidence, could persuade the Appellate Body either to admit the existence of a tacit doctrine of frustration built into the aforementioned articles or to buttress those articles by reaching out to the general doctrine of frustration recognized in the Vienna Convention on the Law of Treaties. ${ }^{225}$

In an earlier article, Professor Reichman also suggested that, under the appropriate circumstances, the safeguard provisions implicit in the objectives set out in Article 7 of the TRIPS Agreement and the public interest exceptions expressly recognized in Article 8 "may legitimize ad hoc exceptions and limitations required by overriding national development needs or for reasons of national health, welfare or security. ${ }^{226}$

Second, as Professor Gervais pointed out, "the reference to social and economic welfare and to a balance of rights and obligations could serve to justify exceptions to exclusive rights, where the right holder has failed to participate in social and economic development or, in other words, has used his rights without performing his obligations."227 Although exceptions and limitations in the copyright and patent systems are generally examined through the three-step test laid out in Articles 13 and 30 of the TRIPS Agreement, ${ }^{228}$ it is important to keep in mind the Appellate Body's reminder in Canada-Patent Protection of Pharmaceutical Products. As the Appellate Body stated, the Vienna Convention requires those interpreting and implementing the TRIPS Agreement to bear in mind the goals

224. J.H. Reichman, The TRIPS Agreement Comes of Age: Conflict or Cooperation with the Developing Countries, 32 CASE W. RES. J. INT'L L. 441, 461 (2000).

225. Id. at 461-62 (footnotes omitted).

226. Reichman, supra note 205 , at 35 .

227. GERVAIS, supra note 2, at 116; accord CORREA, supra note 7, at 97 ("Article 7 (and Article 8) may serve to justify exceptions to exclusive rights where the right-holder has failed to participate in social and economic development.").

228. TRIPS Agreement, supra note 1, arts. 13, 30. 
and limitations stated in Articles 7 and 8.1 when they examine the limiting conditions outlined in the three-step test. ${ }^{229}$

To date, commentators have generally focused on the use of Articles 7 and 8 to promote access to essential medicines in lessdeveloped countries. ${ }^{230}$ However, the two provisions can be used in many other areas. For example, Professor Okediji described how the provisions can be used to justify the validity of the fair use privilege in U.S. copyright law under the TRIPS Agreement. ${ }^{231}$ Srividhya Ragavan also explored the use of the provisions to determine whether a member state has provided an effective sui generis system to protect plant varieties. ${ }^{232}$ Utilizing Article 7 of the TRIPS Agreement, Marco Ricolfi further pointed out:

[E]fforts currently under way to make the patent system mutually supportive with the objective of preserving and fostering biodiversity can be better visualized under the heading of "social welfare," because this notion implies a respect for the autonomy of the (also non-IP) values of indigenous communities that may well defy the flatness of the calculus felicificus at which economists are so adept. ${ }^{23}$

Third, the two provisions are likely to be of increasing importance when countries began to file nonviolation complaints-complaints of nullification or impairment of benefits despite a lack of substantive violations. During the Sixth WTO Ministerial Conference in Hong Kong, WTO members agreed to extend the moratorium on these complaints until the next

229. Panel Report, Canada-Patent Protection of Pharmaceutical Products, II 7.26, WT/DS114/R (Mar. 17, 2000) ("Both the goals and the limitations stated in Articles 7 and 8.1 must obviously be borne in mind when [examining the words of the limiting conditions in Article 30] as well as those of other provisions of the TRIPS Agreement which indicate its object and purposes.").

230. See, e.g., James Thuo Gathii, The Legal Status of the Doha Declaration on TRIPS and Public Health Under the Vienna Convention on the Law of Treaties, 15 HARV. J.L. \& TECH. 291, 304-07 (2002); Reichman, supra note 224, at 461.

231. See Ruth Okediji, Toward an International Fair Use Doctrine, 39 CoLUM. J. TRANSNAT'L L. 75, 167-68 (2000).

232. Srividhya Ragavan \& Jamie Mayer O'Shields, Has India Addressed Its Farmers' Woes? A Story of Plant Protection Issues, 20 GEO. INT'L ENVTL. L. REV. 97, 101 (2007). As Professor Ragavan and her co-author wrote:

In light of Articles 7 and 8 of TRIPS, the effectiveness of a plant protection regime established under Article 27 must be judged by its ability to accommodate local and national welfare and economic goals. Such a reading of the effectiveness requirement fits more comfortably with the other sub-sections of Article 27, which provide that members may choose to protect biological or microbiological materials.

Id. (emphasis omitted).

233. Ricolfi, supra note 109, at 325-26 (footnote omitted). 
ministerial conference. ${ }^{234}$ Although nonviolation complaints are unlikely to present problems for less-developed countries in the near future, problems may arise if the moratorium is finally lifted. ${ }^{235}$

Thus far, the WTO panels and the Appellate Body have expressed their preference for a narrow definition of a right holder's normal exploitation of intellectual property rights. ${ }^{236}$ Based on this logic, a member state's normal expectations concerning the protection and enforcement of those rights will

234. World Trade Organization, Doha Work Programme: Ministerial Declaration, II 45, WT/MIN(05)/DEC (Dec. 22, 2005). Article 64 of the TRIPS Agreement provides: "Subparagraphs 1(b) and 1(c) of Article XXIII of GATT 1994 shall not apply to the settlement of disputes under this Agreement for a period of five years from the date of entry into force of the WTO Agreement." TRIPS Agreement, supra note 1, art. 64.2. Subparagraphs 1(b) and 1(c) of Article XXIII of the GATT 1994 further provide:

If any contracting party should consider that any benefit accruing to it directly or indirectly under this Agreement is being nullified or impaired or that the attainment of any objective of the Agreement is being impeded as the result of ... (b) the application of another contracting party of any measure, whether or not it conflicts with the provisions of this Agreement, or (c) the existence of any other situation ....

General Agreement on Tariffs and Trade art. XXIII(1)(b)-(c), Apr. 15, 1994, Marrakesh Agreement Establishing the World Trade Organization, Annex 1A, Legal InstrumentsResults of the Uruguay Round, 33 I.L.M. 1153 (1994).

The origin of this moratorium can be traced back to the early $1990 \mathrm{~s}$. As the TRIPS Resource Book recounted:

[T] he Dunkel Draft did not address the question of whether non-violation complaints should apply to TRIPS. This issue only arose in the Legal Drafting Group in 1992-93. Some countries argued that TRIPS was substantially different from either the GATT tariff type commitments or the specific commitments undertaken by Members in the GATS context. TRIPS was not about such commitments but about minimum standards. So, these countries took the view that non-violation should not apply to TRIPS at all, or at least it was not clear how non-violation would apply to TRIPS. The rationale behind this view was some Members' concern that the applicability of non-violation complaints to TRIPS might eventually lead to de facto intellectual property standards higher than those actually agreed to during the negotiations.

Other Members, on the other hand, were concerned that the absence of nonviolation complaints would enable governments to undermine their TRIPS obligations by resorting to lawful, but narrow interpretations of the TRIPS protection standards. After discussing the matter thoroughly, parties agreed on a moratorium concerning the applicability of non-violation to TRIPS. This compromise is reflected in the second paragraph of Article 64, which provides for a moratorium for five years during which non-violation shall not apply to TRIPS. Whether or not it applies after this period is a controversial issue.

TRIPS RESOURCE BOOK, supra note 7, at 663-64 (footnotes omitted).

235. In November 2009, shortly before the Seventh WTO Ministerial Conference in Geneva, WTO members reached an agreement to recommend an extension of this moratorium. William New, WTO to Extend Moratorium on Non-Violation Cases, ECommerce Taxes, INTELL. PROP. WATCH, Nov. 6, 2009, http://www.ip-watch.org/weblog/ 2009/11/06/wto-to-extend-moratoriums-on-non-violation-cases-e-commerce-taxes.

236. See Panel Report, United States-Section 110(5) of the U.S. Copyright Act, II 6.167, WT/DS160/R (June 15, 2000). 
also be narrowly interpreted, with a strong emphasis on economic interests. Because "[t]he peculiarity of the notion of non-violation is that it does not, like many other international treaties, focus on the legality of an action, but rather on the protection of expectations arising from reciprocal tariff and market access concessions (in the GATT context) or from a Member's specific commitments (in the GATS context),",237 Articles 7 and 8 are needed to ensure that the WTO panels and the Appellate Body properly divine these expectations.

As Professor Gervais pointed out, based on Article 7, "any country wishing to establish a violation of TRIPS or a nullification or impairment would be well advised to carefully provide in its submissions the data to deal with" the argument that the right holder has failed to participate in social and economic development or has used its rights without performing the accompanying obligations. ${ }^{238}$ Likewise, Professor Correa noted:

Article 8.1 is likely to be important in limiting the potential range of non-violation nullification or impairment causes, if allowed in the context of the TRIPS Agreement, as it makes clear that a wide range of public policy measures eventually changing the balance of concessions should be reasonably expected. Given the broad powers recognized to Members under Article 8.1, a Member challenging a measure adopted by another Member in pursuance of public policy objectives should have the initial burden of proof of inconsistency with the provisions of the TRIPS Agreement. ${ }^{239}$

\section{Sword}

While the provisions can be used as a shield to protect lessdeveloped countries, it remains questionable whether these provisions can also be used as a sword to challenge the existing provisions in developed countries or to enlarge the countries' policy space in the intellectual property area. Within the WTO dispute settlement process, the use of Articles 7 and 8 as the legal basis for any affirmative challenge is likely to be remote. Because Article 7 is only a "should" provision, it does not provide the usual strength of a "shall" provision. ${ }^{240}$ Moreover, given the

237. TRIPS RESOURCE BOOK, supra note 7, at 655 (emphasis added).

238. GERVAIS, supra note 2, at 116-17.

239. CORREA, supra note 7, at 108 (footnotes omitted); see also TRIPS RESOURCE Book, supra note 7, at 127 ("This statement of principle in Article 8.1 should prove important in limiting the potential range of non-violation nullification or impairment causes of action that might be pursued under TRIPS. Article 8.1 indicates that Members were reasonably expected to adopt such TRIPS-consistent measures." (footnote omitted)).

240. See GerVaIS, supra note 2, at 116. 
strong views taken by the European Communities and the United States during the negotiation process, WTO panels and the Appellate Body are likely to distinguish those two provisions from the operative or substantive provisions. Compared to Article 7, Article 8 is even weaker. Both Articles 8.1 and 8.2 use the word "may" and are heavily constrained by the TRIPSconsistency requirement. Article 8.1 is further weakened by an additional necessity requirement.

In one of the leading treatises on the TRIPS Agreement, Professor Gervais suggests that Article 7 "could be invoked to limit an obligation to protect or enforce a given intellectual property right where no promotion of intellectual innovation and/or transfer or dissemination of technology can be proven."241 Although a textual analysis of the provision supports his suggestion, it is rather difficult for a complainant to provide such proof in reality. One may still remember the famous remark of economist Fritz Machlup in his critical examination of the U.S. patent system:

If we did not have a patent system, it would be irresponsible, on the basis of our present knowledge of its economic consequences, to recommend instituting one. But since we have had a patent system for a long time, it would be irresponsible, on the basis of our present knowledge, to recommend abolishing it. ${ }^{242}$

Moreover, the WTO panels and the Appellate Body have adopted a strict textual approach and have practiced judicial restraint. ${ }^{243}$ As the Appellate Body made clear in India-Patent Protection for Pharmaceutical and Agricultural Chemical

241. Id.

242. Staff of Subcomm. on Patents, Trademarks, and Copyrights of the S. COMm. ON THE JUdiciary, 85TH CONG., AN ECONOMIC REview OF THE PATENT SYSTEM 80 (Comm. Print 1958) (study by Fritz Machlup).

243. See, e.g., Barbosa et al., supra note 54, at 99 (noting that some commentators have criticized the restrictive interpretive approach of the WTO panels and the Appellate Body as "aggressively textual"); Okediji, supra note 54, at 889 (noting the "TRIPS panels' strict textual adherence"); Jerome H. Reichman, Securing Compliance with the TRIPS Agreement After US $v$ India, 1 J. INT'L ECON. L. 585, 594-96 (1998) (noting the Appellate Body's endorsement of a "cautious, strict constructionist approach to the TRIPS Agreement" in India-Patent Protection for Pharmaceutical and Agricultural Chemical Products and stating that "[d]eference to local law and strict construction of treaties have ... become the pedestal on which the Appellate Body's TRIPS jurisprudence rests"); J.H.H. Weiler, The Rule of Lawyers and the Ethos of Diplomats: Reflections on the Internal and External Legitimacy of WTO Dispute Settlement, 35 J. WORLD TRADE 191, 206 (2001) (noting "[t]he almost obsessive attempts of the Appellate Body to characterize wherever possible the normal wide-ranging, sophisticated, multifaceted and eminently legitimate interpretations of the Agreement as 'textual' resulting from the ordinary meaning of words"). 
Products, the principles of interpretation set out in Article 31 of the Vienna Convention "neither require nor condone the imputation into a treaty of words that are not there or the importation into a treaty of concepts that were not intended."244 Thus far, WTO panels and the Appellate Body have interpreted the TRIPS Agreement narrowly, showing great deference to the Vienna Convention, the plain meaning of the text, the context of the TRIPS negotiations, and subsequent developments in the intellectual property field.

Notwithstanding these limitations, Articles 7 and 8 can be used as offensive tools in six different ways. First, although the provisions may not provide the legal basis for challenging intellectual property laws and policies in developed countries in the WTO dispute settlement process, both provisions can be used to strengthen other operative provisions that promote social and economic welfare or that help preserve the balance of the intellectual property system.

Articles 66 and 67 of the TRIPS Agreement, for example, require developed countries to provide technical cooperation to least-developed countries. ${ }^{245}$ Although less-developed countries were concerned that Article 66 is "couched in 'best endeavour' terms, ${ }^{246}$ Paragraph 11.2 of the Doha Ministerial Decision of 14 November 2001, which covers implementation-related issues and concerns, reaffirmed the mandatory nature of the provision. ${ }^{247}$ The decision further required the TRIPS Council to "put in place a mechanism for ensuring the monitoring and full implementation of the obligations in question." ${ }^{248}$ With fortifications from Articles 7 and 8, Articles 66 and 67 are likely to become even more robust and effective.

244. Appellate Body Report, India-Patent Protection for Pharmaceutical and Agricultural Chemical Products, II 45, WT/DS50/AB/R (Dec. 19, 1997).

245. TRIPS Agreement, supra note 1, arts. 66-67.

246. General Council, Preparations for the 1999 Ministerial Conference: The TRIPS Agreement: Communication from Kenya on Behalf of the African Group, ITI 8-9, WT/GC/W/302 (Aug. 6, 1999) [hereinafter Communication from Kenya]; accord CORREA, supra note 7, at 98 ("Developing countries have noted at the Working Group, that most provisions in WTO agreements relating to transfer of technology were of 'best endeavour' nature rather than binding obligations, and that they should be made operational."). As the African Group explained: "Best endeavour provisions are fundamentally flawed in that they are neither enforceable nor do they constitute a real benefit for developing and least-developed countries. Consequently many developed countries have as yet not demonstrated how they are fulfilling the provisions of this Article." Communication from Kenya, supra, III 8-9.

247. World Trade Organization, Implementation-Related Issues and Concerns: Decision of 14 November 2001, ףl 11.2, WT/MIN(01)/17 (Nov. 20, 2001) ("[T]he provisions of Article 66.2 of the TRIPS Agreement are mandatory.").

248. Id. 
In the patent area, Articles 7 and 8 can help strengthen the limitations and exceptions in Articles 27 and 31. Articles 27.2 and 27.3, for example, stipulate the standards for excluding inventions from patentability. ${ }^{249}$ Article 27.3 also preserves the flexibility for member states to design protection for plant varieties. ${ }^{250}$ Article 31 lays down the various conditions under which member states can use patented products without the right holders' authorization. ${ }^{251}$ The two provisions can also help clarify the limiting conditions in Article 30, which provides a three-step test for evaluating limitations and exceptions in the patent field. As shown in Canada-Patent Protection of Pharmaceutical Products, a WTO Panel has used Articles 7 and 8 to clarify the limiting conditions stated in the three-step test. ${ }^{252}$

Second, Articles 7 and 8 may be used to promote the development of maximum standards as well as exceptions and limitations at the TRIPS Council meetings. Paragraph 19 of the Ministerial Declaration instructed the TRIPS Council to take into account "the objectives and principles set out in Articles 7 and 8 of the TRIPS Agreement and ... the development dimension." ${ }^{253}$ While the legal effect of this declaration remains suspect in future challenges before the WTO Dispute Settlement Body, Articles 7 and 8 are likely to receive more attention in the TRIPS Council, which was specifically instructed to take account of those provisions. There is a difference between judicial adjudication on the one hand and political persuasion or diplomatic negotiation on the other. More importantly, the two provisions provide the needed principles and rhetoric that often prevail in international negotiations. ${ }^{254}$ Echoing loudly the demands of less-developed countries, they also provide a strategic reminder of the bargain these countries have struck during the TRIPS negotiations.

In addition, Articles 7 and 8 may feature prominently in the review processes established by the TRIPS Council, WTO bodies, and other international organizations. For example, "[a] number of developing countries have [already] indicated that the

249. TRIPS Agreement, supra note 1, arts. 27.2-.3.

250. Id. art. 27.3 (allowing member states to "provide for the protection of plant varieties either by patents or by an effective sui generis system or by any combination thereof").

251. Id. art. 31.

252. Panel Report, Canada-Patent Protection of Pharmaceutical Products, II 7.26, WT/DS114/R (Mar. 17, 2000).

253. Ministerial Declaration, supra note 60, II 19

254. See Gervais, supra note 42 , at 508 (noting, in retrospect, that "the emerging outlining of a possible TRIPS result had essentially been at the level of principles, not legal texts"). 
implementation of Article 7 should be examined in the Council for TRIPS in the context of determining whether TRIPS is fulfilling the objective of contributing to the dissemination and transfer of technology." ${ }^{255}$ Outside the WTO, Articles 7 and 8 will also make clear the intended objectives of the TRIPS Agreement. In doing so, they promote coherency within the international treaty system while at the same time providing a yardstick for international organizations to determine for themselves whether the Agreement has been properly implemented.

Third, Articles 7 and 8 can be used as a sword in nonviolation complaints just as they can be used as a shield. Although less-developed countries have been rather concerned that they might be on the receiving end of these complaints once the moratorium is lifted, they can also use these complaints to challenge measures in developed countries that alter the balance of the TRIPS regime. In such challenges, Articles 7 and 8 will provide the helpful textual basis to show how the measures have upset the balance of the international intellectual property system, the reasonable expectations these countries had when the TRIPS negotiations entered into effect, and whether their reliance on such expectations is justified. ${ }^{256}$

Fourth, Articles 7 and 8 may help identify the right holders' obligations stipulated explicitly or implicitly in the TRIPS Agreement. ${ }^{257}$ These obligations are essential to maintaining the balance of the international intellectual property system-a key objective of the TRIPS Agreement. While the Agreement clearly delineates the substantive rights of intellectual property holders in each member state, it fails to outline clearly the right holders' obligations. As the High Commissioner for Human Rights declared in her report:

[W] hile the Agreement identifies the need to balance rights with obligations, it gives no guidance on how to achieve this balance. On the one hand, the Agreement sets out in

255. TRIPS RESOURCE BOOK, supra note 7, at 132.

256. Thanks to Rochelle Dreyfuss and Jerome Reichman for asking insightful and important questions about this particular use of Articles 7 and 8.

257. As Brazil declared in a submission to the TRIPS Negotiating Group:

[W] hen one speaks of "rights" of intellectual property owners, one is automatically bound to deal with the subject of "obligations" of these owners.

The objective of such obligations which deserves priority attention is to allow greater access to technological innovation for IPR users. If the whole attention of the discussions is centered on the interests of IPR owners, the balance of the entire IPR system is not taken into account.

TRIPS Negotiating Group, Submission from Brazil, III 16-17, MTN.GNG/NG11/W/30 (Oct. 31, 1988). 
considerable detail the content of intellectual property rights-the requirements for the grant of rights, the duration of protection, the modes of enforcement. On the other hand, the Agreement only alludes to the responsibilities of IP holders that should balance those rights in accordance with its own objectives. The prevention of anti-competitive practices and the abuse of rights, the promotion of technology transfer, special and differential treatment for least developed countries are merely referred to-but unlike the rights it sets out, the Agreement does not establish the content of these responsibilities, or how they should be implemented. ${ }^{258}$

It is therefore no surprise that the United Nations SubCommission on the Protection and Promotion of Human Rights reminded governments "of the primacy of human rights obligations over economic policies and agreements." ${ }^{259}$ Meanwhile, a new authoritative interpretation of the International Covenant on Economic, Social and Cultural Rights (Covenant) also states clearly that "intellectual property is a social product... [with] a social function" and that "the private interests of authors should not be unduly favoured and the public interest in enjoying broad access to their productions should be given due consideration." 260

These emphases on, and reminders of, international human rights obligations are important because the WTO member states all have international obligations outside the intellectual property area. As noted in the TRIPS Resource Book:

Human rights instruments, such as the International Covenant on Economic, Social and Cultural Rights, support a number of the same objectives and principles as Articles 7 and 8 . The various agreements of the International Labour Organization, and the charter of the World Health Organization, support the development-oriented objectives and principles of TRIPS. In the implementation of TRIPS and in any dispute settlement proceedings it will be useful

258. U.N. Econ. \& Soc. Council [ECOSOC], Sub-Comm'n on the Promotion \& Prot. of Human Rights, The Impact of the Agreement on Trade-Related Aspects of Intellectual Property Rights on Human Rights: Report of the High Commissioner, II 23, U.N. Doc. E/CN.4/Sub.2/2001/13 (June 27, 2001).

259. Intellectual Property Rights and Human Rights, Sub-Comm'n on Human Rights Res. 2000/7, II 3, U.N. Doc. E/CN.4/Sub.2/RES/2000/7 (Aug. 17, 2000).

260. ECOSOC, Comm. on Econ., Soc. \& Cultural Rights, General Comment No. 17: The Right of Everyone to Benefit from the Protection of the Moral and Material Interests Resulting from Any Scientific, Literary or Artistic Production of Which He Is the Author (Article 15, Paragraph 1(c), of the Covenant), II 35, U.N. Doc. E/C.12/GC/17 (Jan. 12, 2006) [hereinafter General Comment No. 17]. 
to establish the supportive links between the objectives and principles stated in Articles 7 and 8, and the objectives and principles of other international instruments. ${ }^{261}$

In fact, the use of the word "should" and the references to the "social and economic welfare" and "a balance of rights and obligations" in Article 7 provide a strong reminder of the many obligations imposed by the Covenant, such as the rights to life, food, health, education, self-determination, freedom of expression, cultural participation and development, and the benefits of scientific progress. ${ }^{262}$ Those references also pave the way for the development of substantive obligations with the TRIPS regime.

In recent years, commentators have widely discussed the need to build obligations, responsibilities, maximum standards, and affirmative rights into the intellectual property system. For example, Jacqueline Lipton pointed out that, when laws borrowed from traditional property theory are applied in the information property context, there is a tendency to overlook the fact that "traditional Property rights entail significant concurrent obligations or responsibilities imposed on the proprietary owner as an incident of their Property ownership." ${ }^{263}$ Scholars have also advanced proposals to develop affirmative user rights to facilitate public access to protected materials. ${ }^{264}$ Many of those proposals seek to benefit user groups that are acknowledged implicitly in Article 7, including "libraries, educational institutions, research institutes, or non-governmental organizations[, all of whom] were noticeably absent during TRIPS negotiations." ${ }^{265}$

Fifth, the identification in Article 7 of promoting "social and economic welfare" and "a balance of rights and obligations" as the key objectives of the TRIPS Agreement provides a strong textual basis for less-developed countries and intergovernmental organizations to demand the establishment of impact studies on development, ${ }^{266}$ which have been widely endorsed in the areas of human rights, public health, and biological diversity. ${ }^{267}$ After all,

261. TRIPS RESOURCE BoOK, supra note 7, at 130.

262. International Covenant on Economic, Social and Cultural Rights, Dec. 16, 1966, 993 U.N.T.S. 3.

263. Jacqueline Lipton, Information Property: Rights and Responsibilities, 56 FLA. L. REV. 135, 148 (2004).

264. See Yu, supra note 2, at 396-401 (outlining the various proposals).

265. Okediji, supra note 54 , at 858 .

266. See Yu, supra note 3, at 901 (noting the need to "require impact studies before a further expansion of intellectual property protection").

267. See, e.g., Convention on Biological Diversity art. 14(1)(a), June 5, 1992, 1760 U.N.T.S. 143 (requiring contracting parties to "[i]ntroduce appropriate procedures requiring environmental impact assessment of its proposed projects that are likely to 
welfare and balance cannot be determined in vacuo. The recently adopted WIPO Development Agenda also includes a number of recommendations concerning assessment, evaluation, and impact studies. ${ }^{268}$ These studies are particularly important as intellectual property protection expands to create spillover effects in other policy areas. In fact, it would be good policy to conduct impact studies to undertake a holistic evaluation of the ramifications of all new intellectual property standards before their adoption. ${ }^{269}$

Finally, Articles 7 and 8 can be used to help reframe the existing intellectual property debate. Although legal scholars have widely ignored the importance of such framing and reframing, their importance has been recently picked up by commentators outside the legal discipline or by those having interdisciplinary research interests. ${ }^{270}$ If carefully developed, a constructive frame can effectively convince the WTO member states, the TRIPS Council, WTO panels, and the Appellate Body to become more receptive to the demands, or perhaps pleas, of lessdeveloped countries. ${ }^{271}$ As John Braithwaite and Peter Drahos noted in the public health context: "Had TRIPS been framed as a public health issue, the anxiety of mass publics in the US and other Western states might have become a factor in destabilizing the consensus that US business elites had built around TRIPS.,"272 Likewise, Susan Sell reminded us that "grants talk" is preferable to "rights talk" from the standpoint of international development

have significant adverse effects on biological diversity with a view to avoiding or minimizing such effects and, where appropriate, allow for public participation in such procedures"); General Comment No. 17, supra note 260, II 35 ("States parties should... consider undertaking human rights impact assessments prior to the adoption and after a period of implementation of legislation for the protection of the moral and material interests resulting from one's scientific, literary or artistic productions."); COMM'N ON INTEllectual Prop. RIGHTS, INNOVATION \& PUB. HEALTh, WORLD HEALTH ORG., PUBlic HEALTH, INNOVATION AND INTELLECTUAL PROPERTY RIGHTS 10 (2006), available at http://www.who.int/intellectualproperty/documents/thereport/ENPublicHealthReport.pdf ("Health policies, as well as inter alia those addressing trade, the environment and commerce, should be equally subject to assessments as to their impact on the right to health.").

268. World Intellectual Prop. Org. [WIPO], The 45 Adopted Recommendations Under the WIPO Development Agenda, Cluster D, http://www.wipo.int/ip-development/en/ agenda/recommendations.html (last visited Nov. 21, 2009) [hereinafter 45 Adopted Recommendations].

269. See Yu, supra note 129.

270. DEERE, supra note 132, at 173; Amy Kapczynski, The Access to Knowledge Mobilization and the New Politics of Intellectual Property, 117 YALE L.J. 804, 809 (2008); John S. Odell \& Susan K. Sell, Reframing the Issue: The WTO Coalition on Intellectual Property and Public Health, 2001, in Negotiating Trade: Developing Countries in THE WTO AND NAFTA 85, 87 (John S. Odell ed., 2006); Yu, supra note 4, at 552.

271. See Yu, supra note 37, at 377-78 (discussing the importance of the media in framing and reframing issues in the international debate).

272. JOHN BRATTHWATtE \& PETER DRAHOS, GLOBAL BUSINESS REgUlation 576 (2000). 
because it "highlights the fact that what may be granted may be taken away when such grants conflict with other important goals" and is likely to discourage policymakers from focusing on the entitlement of the rights holders. ${ }^{273}$

\section{Bridge}

Articles 7 and 8 can serve as a useful bridge that connects the TRIPS regime with those other regimes that may be implicated by the protection and enforcement of intellectual property rights. Paragraph 19 of the Ministerial Declaration, for example, stated explicitly that the TRIPS Council should be guided by Articles 7 and 8 in its examination of "the relationship between the TRIPS Agreement and the Convention on Biological Diversity [and] the protection of traditional knowledge and folklore." ${ }^{274}$ Such protection, after all, can be covered in many different regimes-most notably, the biodiversity regime and the food and agriculture regime.

Likewise, the language of Article 7 has recently been incorporated into a recommendation adopted as part of the WIPO Development Agenda. As Recommendation 45 states specifically:

To approach intellectual property enforcement in the context of broader societal interests and especially developmentoriented concerns, with a view that "the protection and enforcement of intellectual property rights should contribute to the promotion of technological innovation and to the transfer and dissemination of technology, to the mutual advantage of producers and users of technological knowledge and in a manner conducive to social and economic welfare, and to a balance of rights and obligations," in accordance with Article 7 of the TRIPS Agreement. ${ }^{275}$

Articles 7 and 8 of the TRIPS Agreement, therefore, are important for maintaining the balance in not just the TRIPS regime, but also in the global innovation system.

Today, international law has become highly fragmented, ${ }^{276}$ and the continuous proliferation of international fora and the

273. SELL, supra note 38 , at 146.

274. Ministerial Declaration, supra note 60, $\mathbb{1 9}$.

275. 45 Adopted Recommendations, supra note 268, Recommendation 45 (quoting TRIPS Agreement, supra note 1, art. 7).

276. See generally Eyal Benvenisti \& George W. Downs, The Empire's New Clothes: Political Economy and the Fragmentation of International Law, 60 STAN. L. REV. 595 (2007) (discussing the growing fragmentation of international law and "the increased proliferation of international regulatory institutions with overlapping jurisdictions and ambiguous boundaries"). 
widespread use of regime-shifting maneuvers have led to the development of intellectual property-related norms in many different international fora. ${ }^{277}$ This development has resulted in the creation of what I have described as the "international intellectual property regime complex"-a larger conglomerate regime that includes not only the traditional area of intellectual property laws and policies, but also the overlapping areas in related regimes or fora. ${ }^{278}$

Thus, while it remains important to strengthen safeguards in the international intellectual property system, or develop the so-called ceilings of or maximum standards for intellectual property protection and enforcement, it is equally important to develop support in other international instruments that can be used to enhance the impact of Articles 7 and 8 within the TRIPS Agreement. With the support of these additional standards, Articles 7 and 8 may more effectively "persuade the [WTO panels and the Appellate Body] to recognize and give effect to developmental priorities."279 In fact, "it may be useful in the context of dispute settlement to cross-reference developmental objectives and principles of the appropriate agreements. ${ }^{\text {"280 }}$ After all, the Preamble of the TRIPS Agreement states the drafters' intention to "[r]ecogniz[e] the underlying public policy objectives of national systems for the protection of intellectual property, including developmental and technological objectives." ${ }^{281}$

This approach makes a lot of sense. As Professor Correa pointed out, "[i]ntellectual property cannot be regarded in isolation from broader national policies, such as competition and development policies. In order to contribute to national objectives, the intellectual property system must be integrated into such policies. ${ }^{228}$ Likewise, Graeme Austin noted:

To the extent that intellectual property policies and values can be identified, it might be more helpful to regard them

277. See BRAITHWAITE \& DRAHOS, supra note 272, at 564-71 (discussing the use of forum shifting); MAY, supra note 163, at 66 (discussing forum proliferation); Laurence $\mathrm{R}$. Helfer, Regime Shifting: The TRIPs Agreement and New Dynamics of International Intellectual Property Lawmaking, 29 YALE J. INT'L L. 1 (2004) (discussing the use of regime shifting).

278. See Yu, supra note 151, at 13-21; see also Kal Raustiala \& David G. Victor, The Regime Complex for Plant Genetic Resources, 58 INT'L ORG. 277, 279 (2004) (originating the concept of a "regime complex," which was defined as "an array of partially overlapping and nonhierarchical institutions governing a particular issue-area"); David W. Leebron, Linkages, 96 AM. J. INT'L L. 5, 18-19 (2002) (advancing the concept of a "conglomerate regime").

279. TRIPS RESOURCE BOOK, supra note 7, at 130.

280. Id.

281. TRIPS Agreement, supra note 1, pmbl. recital 5.

282. CORREA, supra note 7 , at 12 . 
as aspects of much broader issues of public policy. Policies that help ensure that populations get fed, enjoy the benefits of literacy, are healthy, have viable agricultural bases, and can participate in technological and cultural developmentthese seem to be the kinds of policies that should have priority in any analysis of the values that intellectual property laws are meant to serve. ${ }^{283}$

Most recently, Henning Ruse-Khan also suggested the use of "the WTO-overarching objective of sustainable development as a principle for reconciling economic, social and environment[al] interests which applies to all WTO Agreements," including the TRIPS Agreement. ${ }^{284}$

Like these commentators, the WTO Dispute Settlement Body has acknowledged the overlap between intellectual property protection and protection under other international regimes. In its first dispute, United States-Standards for Reformulated and Conventional Gasoline, the Appellate Body declared that "the General Agreement [which consists of agreements in many different areas] is not to be read in clinical isolation from public international law." ${ }^{285}$ In India-Patent Protection for Pharmaceutical and Agricultural Chemical Products, the WTO Panel also recognized that the TRIPS Agreement "is an integral part of the WTO system, which itself builds upon the experience over nearly half a century" under the GATT. ${ }^{286}$ Moreover, in United States-Import Prohibition on Certain Shrimp and Shrimp Turtle Products, the Appellate Body "moved firmly away from the notion of the WTO as a 'selfcontained' legal regime.".287

\section{E. Seed}

Articles 7 and 8 can be used as a seed for the development of new norms both within and without the international intellectual

283. Graeme W. Austin, Valuing "Domestic Self-Determination" in International Intellectual Property Jurisprudence, 77 CHI.-KENT L. REV. 1155, 1193 (2002) (footnote omitted).

284. Ruse-Khan, supra note 85 , at 62.

285. Appellate Body Report, United States-Standards for Reformulated and Conventional Gasoline, pt. III.B, WT/DS2/AB/R (Apr. 29, 1996).

286. Panel Report, India-Patent Protection for Pharmaceutical and Agricultural Chemical Products, II 7.19, WT/DS50/R (Sept. 5, 1997); see also Marrakesh Agreement, supra note 1, art. II(2) ("The agreements and associated legal instruments included in Annexes 1, 2 and 3 [including the TRIPS Agreement in Annex 1C] are integral parts of this Agreement, binding on all Members.").

287. TRIPS RESOURCE BOOK, supra note 7, at 130 (citing Appellate Body Report, United States-Import Prohibition on Certain Shrimp and Shrimp Turtle Products, WT/DS58/AB/R (Oct. 12, 1998)). 
property regime. ${ }^{288}$ They can supply the needed language or provide direction for the development of these new norms. They also help remind the treaty drafters of the nature, scope, and objectives of intellectual property norms.

In designing the internal norms, Articles 7 and 8 can be used in two ways. First, by stating the objectives and principles of the TRIPS Agreement, the two provisions highlight the concerns of less-developed countries as well as those areas that need greater balancing. For example, Article 8 mentions public health and restraint on trade. ${ }^{289}$ Those provisions therefore underscore the important interfaces between intellectual property protection and the protection of public health or between intellectual property protection and regulation of anticompetitive and restrictive business practices. ${ }^{290}$

Second, Articles 7 and 8 provide objective evidence for determining whether an international political consensus exists. The provisions therefore outline the boundaries of the TRIPS regime. Delineating these boundaries clearly is particularly important as countries increasingly induce others to transplant laws through bilateral, regional, and multilateral efforts. ${ }^{291}$ As Abdulqawi Yusuf aptly suggests, the objectives set forth in Article 7 of the TRIPS Agreement also "provide the overall criteria against which the adequacy and effectiveness of national legislation for the protection and enforcement of IPRs should be measured."292

Although countries that comply with their TRIPS obligations can be hardly described as offering ineffective or inadequate protection-at least according to the TRIPS Agreement ${ }^{293}$ - the

288. These norms may take the form of substantive rules or standards, procedural safeguards, or even equitable remedies.

289. TRIPS Agreement, supra note 1, art. 8.

290. See Ricolfi, supra note 109 , at 326 ("It would seem to me that pro-competitive concerns, including access by 'users of technological knowledge' under Article 7 . . rank pretty high in the list of the[ ] other purposes that are declared relevant by TRIPs principles."). For further discussion of the interface between intellectual property protection and competition law and policy, see Carlos M. Correa, Intellectual Property and Competition Law (ICTSD Programme on IPRs and Sustainable Development, Issue Paper No. 21, 2007); John T. Cross \& Peter K. Yu, Competition Law and Copyright Misuse, 56 DRAKE L. REV. 427 (2008); Ricolfi, supra note 109.

291. See Yu, supra note 3, at 855-72.

292. Yusuf, supra note 34, at 13.

293. As Professor Correa declared:

What is "effective" and "adequate" protection may be subject to different interpretations. For the purposes of implementing the TRIPS Agreement, however, national standards of protection consistent with the Agreement's obligations are to be considered "effective" and "adequate." There is no room, hence, for an argument of non-effectiveness or non-adequateness to justify demands of "TRIPS-plus" protection (that is, beyond the TRIPS standards) as 
United States Trade Representative can take Section 301 actions on countries that fail to provide "adequate and effective protection of intellectual property rights notwithstanding the fact that [they] may be in compliance with the specific obligations of the Agreement on Trade-Related Aspects of Intellectual Property Rights. ${ }^{224}$ It is, therefore, no surprise that Canada has been put on the Section 301 watch list perennially, along with countries that are, from the U.S. perspective, more likely to have laws in violation of the TRIPS Agreement, such as Brazil, China, India, Russia, and Ukraine. ${ }^{295}$

While the previous three sections focus primarily on developments within the TRIPS regime, that regime is only part of the larger international intellectual property system. In fact, shortly after the Agreement entered into force, WIPO quickly adopted the WIPO Copyright Treaty and the WIPO Performances and Phonograms Treaty. ${ }^{296}$ The organization also developed soft-law recommendations on the protection of wellknown marks and marks on the Internet. ${ }^{297}$ As Professor Dinwoodie observed:

[T] international intellectual property lawmaking process seemed to energize WIPO, resulting in the conclusion of several new treaties in copyright, patent and trademark law, as well as the reorganization ... . designed to make WIPO fit for the twenty-first century.

In the past few years, WIPO has explored the development of a Substantive Patent Law Treaty ${ }^{299}$ and the WIPO Treaty on the

required in some bilateral agreements and FTAs entered into by a number of developed and developing countries ... with US and the EC ...

CORREA, supra note 7, at 1-2.

294. 19 U.S.C. $\$ 2411$ (d)(3)(B)(i)(II) (2006) (emphasis added).

295. See IP Justice, United States Trade Representative (USTR) Section 301 Annual Reports (2001-2007), http://ipjustice.org/USTR/Section_301_Table_2001-2007.htm (last visited Nov. 21, 2009).

296. WIPO Copyright Treaty, adopted Dec. 20, 1996, S. TREATY DoC. No. 105-17, at 1 (1997); WIPO Performances and Phonograms Treaty, adopted Dec. 20, 1996, S. TREATY Doc. No. 105-17, at 18 (1997).

297. WIPO, Joint Recommendation Concerning Provisions on the Protection of WellKnown Marks, WIPO Doc. 833(E) (Sept. 1999); WIPO, Joint Recommendation Concerning Provisions on the Protection of Marks, and Other Industrial Property Rights in Signs, on the Internet, WIPO Doc. 845(E) (Oct. 2001).

298. Dinwoodie, supra note 214, at 1005 (footnotes omitted); accord GERVAIS, supra note 2 , at 82 ("WIPO [may] continue to be the primary forum for major norm-setting efforts and those efforts will then serve as a basis for future changes to the [TRIPS] Agreement.").

299. See Jerome H. Reichman \& Rochelle Cooper Dreyfuss, Harmonization Without Consensus: Critical Reflections on Drafting a Substantive Patent Law Treaty, 57 DUKE L.J. 85, 89-93 (2007) (critiquing the proposed Substantive Patent Law Treaty). 
Protection of Broadcasting Organisations. ${ }^{300}$ Nevertheless, it has faced significant opposition in both areas. ${ }^{301}$

Articles 7 and 8 are equally helpful in developing external norms. While some of these norms may be complementary to or compatible with existing internal norms, others may be what commentators have called "counterregime norms. ${ }^{302}$ As Laurence Helfer defined, counterregime norms are "binding treaty rules and nonbinding soft law standards that seek to alter the prevailing legal landscape. ${ }^{\text {"303 }}$ Once developed, these norms can help set up maximum standards for intellectual property protection. They may also be further internalized within the intellectual property regime as "revisionist norms." 304 As the impact of intellectual property protection continues to spill over into other areas, such as agriculture, health, the environment, education, culture, competition, free speech, democracy, and the rule of law, these revisionist norms will only become more important. ${ }^{305}$

300. See Standing Comm. on Copyright \& Related Rights, WIPO, The WIPO Treaty on the Protection of Broadcasting Organisations, SCCR/17/INF/1 (Nov. 3, 2008).

301. See Monika Ermert, G8 Governments Want ACTA Finalised This Year, SPLT Talks Accelerated, INTELL. PROP. WATCH, July 9, 2008, http://www.ip-watch.org/weblog/ 2008/07/09/g8-governments-want-acta-finalised-this-year-splt-talks-accelerated ("The SPLT did not see much progress in several negotiating rounds at the World Intellectual Property Organisation (WIPO) in recent years."); William New, WIPO Committee Advances Agenda on Copyright Exceptions, Broadcasting, InTELl. Prop. Watch, Nov. 9, 2008, http:/www.ip-watch.org/weblog/2008/11/09/wipo-committee-advances-agenda-onexceptions-to-copyright-broadcasting ('The discussion of broadcasters' rights has dominated the committee agenda for 10 years, culminating in a high-profile failure to agree on a draft treaty text in 2007.").

302. See Helfer, supra note 277, at 58-59 (discussing how less-developed countries can use a strategy of "regime shifting" to develop counterregime norms that set up maximum standards of intellectual property protection).

303. Id. at 14 .

304. Laurence R. Helfer, Mediating Interactions in an Expanding International Intellectual Property Regime, 36 CASE W. RES. J. INT'L L. 123, 127 (2004).

305. Professor Abbott suggested that these norms will become even more important if the moratorium on non-violation complaints is finally lifted. As he explained:

There are many forms of government regulation that could be argued to be consistent with the TRIPS Agreement, yet to nullify or impair the expectations of IPRs holders. For example, tax policies with respect to IPRs may affect the profitability of IPRs-dependent industries and nullify or impair benefits. Regulatory measures such as packaging and labelling requirements, and consumer protection rules, might be applicable to trademark holders and affect their access to the market.

Many Members maintain rules on acceptable expression, that is, they censor certain materials as against public policy. Members on behalf of copyright holders may argue that rules restricting expression are inconsistent with copyright holders' interests.

... [T] he EC and other Members regulate access to the market for expressive works based on cultural concerns. This inhibits market access by 
Although many commentators still perceive international organizations, such as WIPO and the WTO, as self-interested players, ${ }^{306}$ these organizations are beginning to cooperate with each other more-regardless of whether they do it willingly or reluctantly. Article 68 of the TRIPS Agreement states specifically that the Council for TRIPS "may consult with and seek information from any source it deems appropriate" in carrying out its functions and "shall seek to establish, within one year of its first meeting, appropriate arrangements for cooperation with bodies of [WIPO]. ${ }^{307}$ The Agreement Between the World Intellectual Property Organization and the World Trade Organization also calls for cooperation between the WTO and WIPO in the notification of, provision of access to, and translation of national legislation; the communication of national emblems and transmittal of objections pursuant to Article 6ter of the Paris Convention; and legal-technical assistance and technical cooperation. ${ }^{308}$

Indeed, as intellectual property protection expands and as issue areas and international regimes continue to overlap with each other, there will be an increasing and more active flow of language, concepts, standards, measures, and safeguards from one regime to another. While the WTO panels and the Appellate Body remain faithful to the application of the Vienna Convention, they have increasingly looked to treaties in the WIPO or other fora to resolve ambiguities in the TRIPS Agreement. The converse can also be true. It would indeed be no surprise if drafters in other fora or interpreters of nonintellectual property treaties look to Articles 7 and 8 to help

copyright holders and might form the subject of a non-violation complaint.

Frederick M. Abbott, Non-Violation Nullification or Impairment Causes of Action Under the TRIPS Agreement and the Fifth Ministerial Conference: $A$ Warning and Reminder 2 (Quaker United Nations Office, Occasional Paper No. 11, 2003), available at http://www.quno.org/geneva/pdf/economic/Occassional/Non-Violation.pdf.

306. See, e.g., MAY, supra note 163 , at 59 ("WIPO does not merely operate on the basis of the clearly articulated interest of a majority of its members."); Frederick M. Abbott, Distributed Governance at the WTO-WIPO: An Evolving Model for OpenArchitecture Integrated Governance, 3 J. INT'L ECON. L. 63, 72 (2000) (“The WIPO Domain Name Process is the leading example of a multilateral secretariat-based rule-making process which breaks from the traditional model of the passive secretariat."); Dinwoodie, supra note 214, at 1001 ("WIPO acted at the request of a single member state (the United States) to produce a report that, by virtue of delegation of de facto control of the domain name registration process from that single government, could be implemented by ICANN as substantive law without the usual airings found in the intergovernmental lawmaking process of which WIPO is a part." (footnote omitted)).

307. TRIPS Agreement, supra note 1, art. 68.

308. Agreement Between the World Intellectual Property Organization and the World Trade Organization, Dec. 22, 1995, 35 I.L.M. 754 (1996). 
resolve ambiguities in existing treaties, alleviate tension between and among the various treaties, or even to provide a starting point for new treaties and initiatives.

\section{CONCLUSION}

Since their creation and limited application in the early days of the WTO, Articles 7 and 8 have attracted growing attention from policymakers, commentators, intergovernmental organizations, and nongovernmental organizations. Legally, the two provisions play important roles in the interpretation and implementation of the TRIPS Agreement. Economically, they facilitate innovation, technology transfer, and knowledge production while at the same time promoting social and economic welfare and development goals. Politically, they provide the much-needed balance to make the Agreement a legitimate bargain between developed and less-developed countries. Structurally, the two provisions bridge the gap between the TRIPS regime and other international regimes. Globally, they have sowed the seeds for the development of new international norms both within and without the TRIPS regime. Although most of the draft language proposed by less-developed countries did not make its way to the TRIPS Agreement, the choice of such language for Articles 7 and 8 is more than consolation. In fact, it may be a blessing in disguise! Whether the two provisions can become a true blessing, however, will depend on whether the WTO member states can use them effectively, to their advantage, and to the fullest possible extent. 